\title{
Intensive Archaeological Survey of the Proposed SAWS NWC Bulverde/1604 Sewer Extension Project, San Antonio, Bexar County, Texas
}

Virginia Moore

Shawn Marceaux

Follow this and additional works at: https://scholarworks.sfasu.edu/ita

Part of the American Material Culture Commons, Archaeological Anthropology Commons, Environmental Studies Commons, Other American Studies Commons, Other Arts and Humanities Commons, Other History of Art, Architecture, and Archaeology Commons, and the United States History Commons

Tell us how this article helped you.

This Article is brought to you for free and open access by the Center for Regional Heritage Research at SFA ScholarWorks. It has been accepted for inclusion in Index of Texas Archaeology: Open Access Gray Literature from the Lone Star State by an authorized editor of SFA ScholarWorks. For more information, please contact cdsscholarworks@sfasu.edu. 
Intensive Archaeological Survey of the Proposed SAWS NWC Bulverde/1604

Sewer Extension Project, San Antonio, Bexar County, Texas

\section{Creative Commons License}

(c) (1) (8)

This work is licensed under a Creative Commons Attribution-NonCommercial 4.0 International License 


\title{
Intensive Archaeological Survey of the Proposed SAWS NWC Bulverde/1604 Sewer Extension Project, San Antonio, Bexar County, Texas
}

\author{
Antiquities Permit No. 8161 \\ Principal Investigator: Virginia Moore M.A.G. \\ Prepared for: \\ San Antonio Water System \\ 2800 US Highway $281 \mathrm{~N}$ \\ San Antonio, Texas 78212 \\ Report Authors: \\ Virginia Moore, MAG; P. Shawn Marceaux, Ph.D. \\ Pape-Dawson \\ 10801 N. Mopac Expy. \\ Bldg. 3, Suite 200 \\ Austin, TX 78759
}

December 2019 


\begin{abstract}
On behalf of Oden Hughes, Pape-Dawson conducted an intensive archaeological survey of the proposed NWC Bulverde/1604 Sewer Extension Project in San Antonio, Bexar County, Texas. The project proposed to begin on the southwest side of Classen Road approximately 0.2 kilometers $(\mathrm{km})(0.13$ mile [mi]) east of its northern intersection with Bulverde Road. The proposed line would parallel Elm Waterhole Creek to the west and south approximately $0.8 \mathrm{~km}(0.5 \mathrm{mi})$. At this point, the line would cross Autry Pond Road in a southwestern direction eventually paralleling Bulverde Road to the intersection of Redland Road for a total length of approximately $0.4 \mathrm{~km}(0.25 \mathrm{mi})$. This project would entail the installation of $1.2 \mathrm{~km}(0.75$ $\mathrm{mi})$ of new sewer line within a 5-meter $(\mathrm{m})$ (16-foot [ft])-wide permanent easement and an adjacent 8-m (25-ft)-wide temporary easement along whichever side was available. The Area of Potential Effects (APE) for the proposed project was defined as a $30 \mathrm{~m}$ (100 ft) buffer centered on the proposed SAWS centerline totaling 3.7 hectares (ha) (9.18 acres). The depth of vertical impacts was not yet been determined, but utility installations typically require 1.8 to $2.4 \mathrm{~m} \mathrm{(6} \mathrm{to} 8 \mathrm{ft}$ ). Notably, the sewer alignment was changed after completion of this archaeological survey and installation will no longer take place in this APE. The survey for the new alignment was completed under Texas Antiquities Permit \#8870.

Although Oden Hughes would construct the new sewer line, San Antonio Water Systems (SAWS) would be the grantee of the easement after construction. For this reason, compliance with the Antiquities Code of Texas (ACT) was required. In addition, this project would require a Nationwide Permit from the U.S. Army Corps of Engineers (USACE). Thus, compliance with Section 106 of the National Historic Preservation Act (NHPA) (Title 36 Code of Federal Regulations Part 800.4 [36 CFR 800.4]) was required. In addition, the project was located within the San Antonio city limits, which necessitated compliance with the Historic Preservation and Urban Design Section of the City of San Antonio (COSA) Unified Development Code (UDC).
\end{abstract}

Pape-Dawson conducted the intensive archaeological survey on September 20, 2017. The entirety of the APE was subject to visual inspection supplemented by judgmentally placed shovel tests in order to evaluate the potential for buried cultural resources. This work was conducted under Antiquities Permit No. 8161 with Virginia Moore, M.A.G. serving as Principal Investigator. A total of 16 shovel tests was excavated within the APE, all of which were negative for archaeological material. During this survey, one previously recorded site (41BX1786) was revisited within the limits of the APE. However, no cultural deposits associated with the site were encountered. Given the absence of artifacts observed during the current survey, Pape-Dawson recommends that 41BX1786 is ineligible within ROW for State Antiquities Landmark (SAL) and National Register of Historic Places (NRHP) designation.

No archaeological resources were located or recorded during this survey. As no properties were identified that meet the criteria for listing in the National Register of Historic Places (NRHP) according to 36 CFR 60.4, or for designation as a State Antiquities Landmark (SAL) according to 13 Texas Administrative Code 26.12 (13 TAC 26.12), Pape-Dawson recommends that no further archaeological work is necessary for the proposed undertaking as presently designed. However, if undiscovered cultural material is encountered 
during construction, it is recommended that all work in the vicinity should cease and the THC and COSA archaeologists be contacted to ensure compliance with the NHPA, ACT, and UDC. No artifacts were collected, but all project records and photographs will be curated at the Center for Archaeological Research (CAR) at the University of Texas at San Antonio. 


\section{Table of Contents}

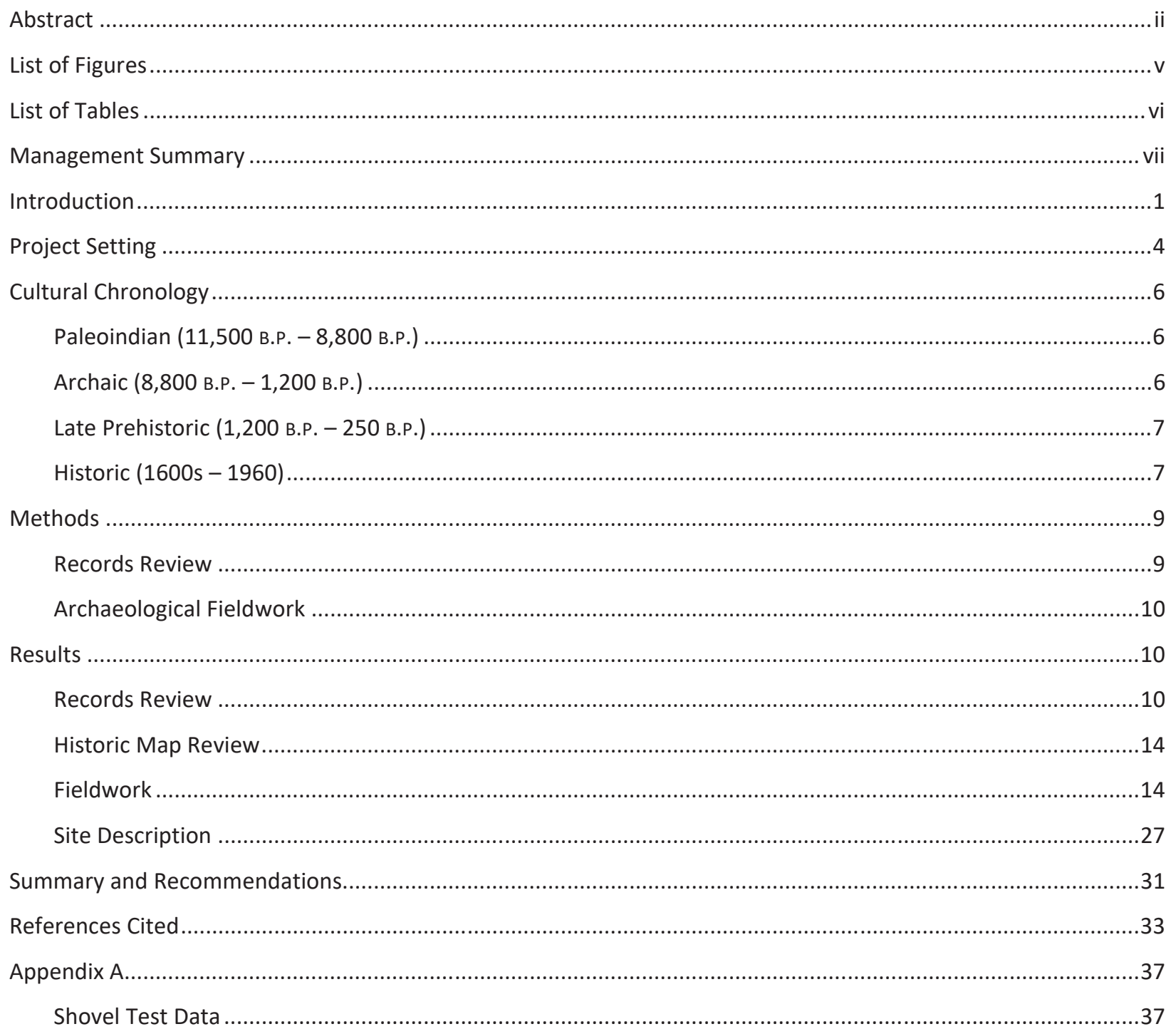




\section{List of Figures}

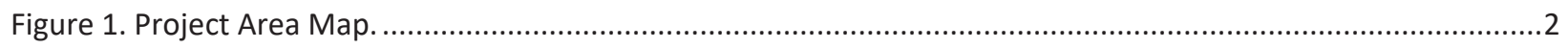

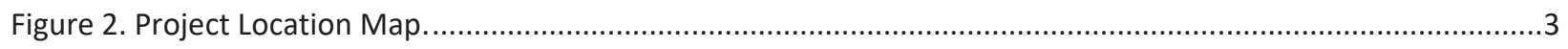

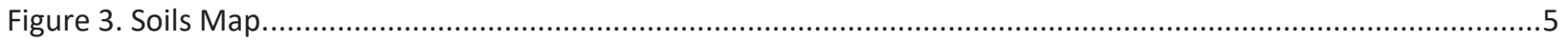

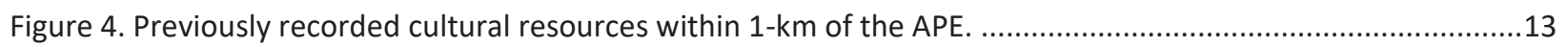

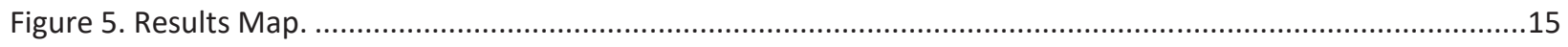

Figure 6. APE west of Classen Road and south of Elm Waterhole Creek, camera facing northwest........................16

Figure 7. Limestone cobbles on the surface in the APE, camera facing east.....................................................17

Figure 8. Elm Waterhole Creek channel crossing the APE west of Bulverde Road, camera facing west....................17

Figure 9. Southwestern end of APE at Redland Road and Bulverde Road, camera facing north. ...........................18

Figure 10. Example of wetlands within the APE, camera facing west. ..........................................................18

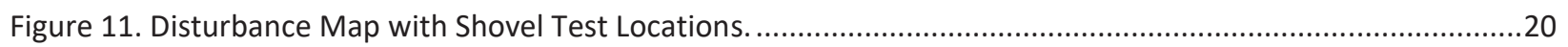

Figure 12. Existing sewer line west of Classen Road in the ROW and APE (runs to the west). ...............................21

Figure 13. Existing sewer line within the APE, camera facing west. Site 41BX1786 is in the tree line on the right. ..21

Figure 14. Disturbance associated with the construction of Bulverde Road, and sidewalks within the existing APE,

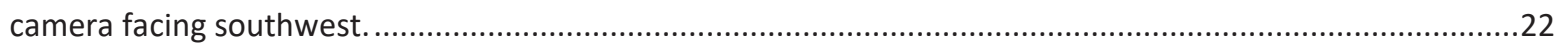

Figure 15. Built up sidewalk area adjacent to Bulverde Road within APE, camera facing northeast........................22

Figure 16. Water Main manhole and sprinkler system access hatch (left center) within the APE, camera facing

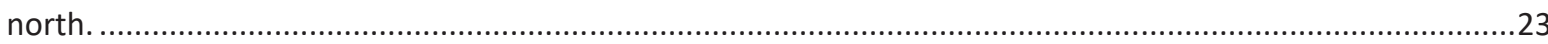

Figure 17. Large culvert running under Bulverde Road at the southern end of the APE, camera facing west. .........23

Figure 18. Disturbance along the western end of the APE, camera facing northeast (former location of Bulverde

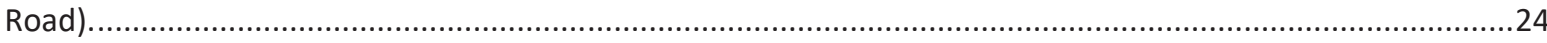

Figure 19. Example of shovel tests (VM01) with intact soils in the APE with large cobbles at $37 \mathrm{cmbs} . . . \ldots \ldots \ldots \ldots . . . .25$

Figure 20. Example of shovel test (MV04) north of Elm Waterhole Creek with impassable cobbles. ......................26

Figure 21. Example of shovel test (MV07) containing disturbed fill along western end of APE..............................26

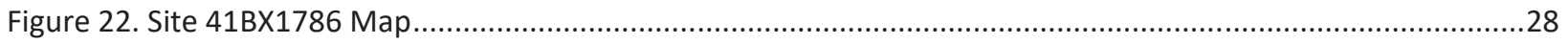

Figure 23. Overview of 41BX1786 from proposed centerline camera facing northwest. .......................................29

Figure 24. General view of 41BX1786 within the wooded sections of the APE, camera facing west. ......................29

Figure 25. Example of less vegetated portions of 41BX1786, with dense short to medium grasses, camera facing

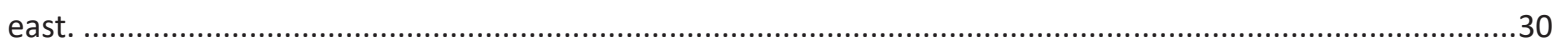

Figure 26. Typical shovel test profile encountered in site 41BX1786....................................................... 


\section{List of Tables}

Table 1. Previously Recorded Archaeological Sites within $1 \mathrm{~km}(0.62 \mathrm{mile})$ of the APE. ........ 


\section{Management Summary}

Oden Hughes proposed to construct a new utility line in northern San Antonio, Bexar County, Texas. The project would begin on the southwest side of Classen Road approximately $0.2 \mathrm{~km}$ ( 0.13 mile) east of its northern intersection with Bulverde Road. The proposed sewer line would parallel Elm Waterhole Creek to the west and south for approximately $0.8 \mathrm{~km}$ ( $0.5 \mathrm{mile})$. At this point, the sewer line would cross Autry Pond Road at a southwestern angle to then parallel Bulverde Road to the intersection of Redland Road, a total distance of approximately $0.4 \mathrm{~km}(0.25$ mile). This project would entail the installation of $1.2 \mathrm{~km}$ ( 0.75 mile) of new sewer line within a 5-m (16-ft)-wide permanent easement and an adjacent 8-m (25-ft)wide temporary easement along whichever side is available. The APE for the proposed project was defined as a $30 \mathrm{~m}$ (100 ft) buffer centered on the proposed SAWS centerline totaling 3.7 ha ( 9.18 acres). The depth of vertical impacts was not determined, but utility installations typically require 1.8 to $2.4 \mathrm{~m} \mathrm{(6} \mathrm{to} 8 \mathrm{ft}$ ). Notably, the sewer alignment was changed after completion of this archaeological survey and installation will no longer take place in this APE. The survey for the new alignment was completed under Texas Antiquities Permit \#8870.

Although Oden Hughes would construct the new utility line, SAWS would be the grantee of the easement after construction. For this reason, compliance with the ACT was required. In addition, this project would require a Nationwide Permit from the USACE. Thus, compliance with Section 106 of the NHPA (36 CFR 800.4) was required. In addition, the project was located within the San Antonio city limits, which necessitates compliance with the Historic Preservation and Urban Design Section of the COSA UDC.

Pape-Dawson conducted the intensive archaeological survey on September 20, 2017. Virginia Moore served as Principal Investigator and was assisted in the field by Megan Veltri. This work was conducted under Antiquities Permit No. 8161. During this survey, one previously recorded site (41BX1786) was revisited within the limits of the APE. However, no cultural material associated with the site were encountered. Given the absence of artifacts observed during the current survey, PapeDawson recommends that $41 \mathrm{BX} 1786$ is ineligible within ROW for State Antiquities Landmark (SAL) and National Register of Historic Places (NRHP) designation. Pape-Dawson recommends that no further archaeological work is necessary for the proposed undertaking as presently designed and that the project be allowed to proceed within the APE. No artifacts were collected, but all project records and photographs will be curated at CAR-UTSA. 


\section{Introduction}

On behalf of Oden Hughes and San Antonio Water System (SAWS), Pape-Dawson conducted an intensive archaeological survey of the proposed NWC Bulverde/1604 Sewer Extension Project in San Antonio, Bexar County, Texas. (Figure 1 and Figure 2). The project would begin on the northeast side of Classen Road approximately 0.2 kilometer $(\mathrm{km})(0.13$ mile) east of its northern intersection with Bulverde Road. The proposed sewer line would parallel Elm Waterhole Creek to the southwest approximately $0.8 \mathrm{~km}(0.5$ mile). At this point, the sewer line would cross Autry Pond Road turning south and paralleling Bulverde Road to its intersection with Redland Road a distance of approximately $0.4 \mathrm{~km}$ ( 0.25 mile). This project would entail the installation of $1.2 \mathrm{~km}$ ( 0.75 mile) of new sewer line within a 5-meter $(\mathrm{m})$ (16-foot [ft])wide permanent easement and an adjacent 8-m (25-ft)-wide temporary easement along whichever side was available. The Area of Potential Effects (APE) for the proposed project was defined as a $30 \mathrm{~m} \mathrm{(100} \mathrm{ft)}$ buffer centered on the proposed SAWS centerline with total area of 3.7 hectares (ha) (9.18 acres). The depth of vertical impacts was not yet determined, but utility installations typically require 1.8 to $2.4 \mathrm{~m}$ (6 to $8 \mathrm{ft}$ ). Notably, the sewer alignment was changed after completion of this archaeological survey and installation will no longer take place in this APE. The survey for the new alignment was completed under Texas Antiquities Permit \#8870.

SAWS would be the grantee of the easement after construction; therefore, compliance with the Antiquities Code of Texas (ACT) was required. In addition, this project required a Nationwide Permit from the U.S. Army Corps of Engineers (USACE). Thus, compliance with Section 106 of the National Historic Preservation Act (NHPA) (Title 36 Code of Federal Regulations Part 800.4 [36 CFR 800.4]) was required. This scope of work included compliance with both regulations. In addition, the project was located within the San Antonio city limits, which necessitated compliance with the Historic Preservation and Urban Design Section of the City of San Antonio (COSA) Unified Development Code (UDC).

Pape-Dawson conducted the intensive cultural resources survey for the proposed SAWS sewer line on September 20, 2017. The 1.2-km (0.75-mile) APE was subjected to visual inspection and shovel testing. Virginia Moore served as Principal Investigator and was assisted in the field by Megan Veltri. The goals of the investigation were to: (1) locate all prehistoric and historic archaeological sites, if present, within the APE; (2) establish vertical and horizontal site boundaries, as appropriate with respect to the APE; (3) evaluate the significance of recorded sites and structures with regard to National Register of Historic Places (NRHP) and State Antiquities Landmark (SAL) eligibility. 


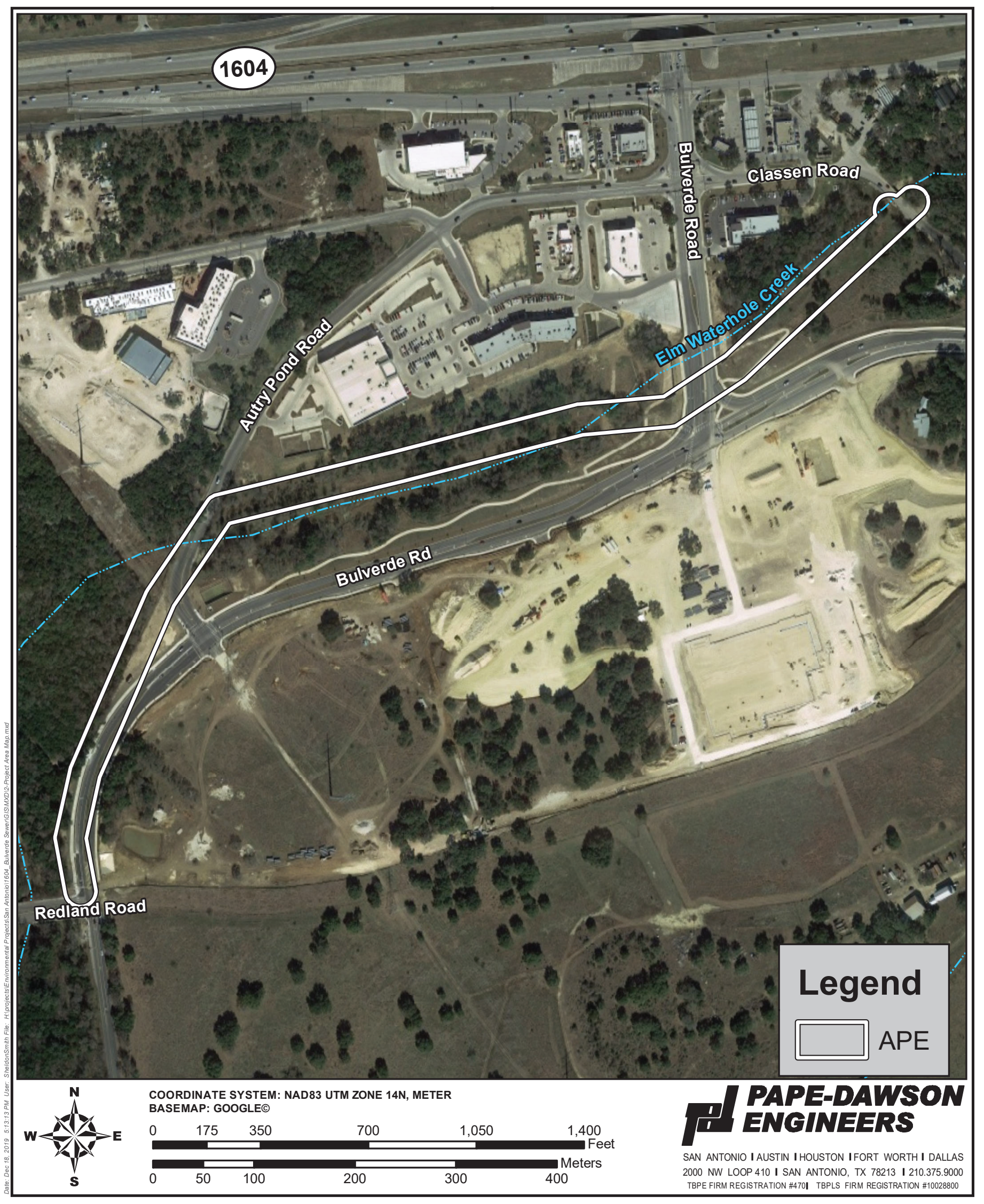

Figure 1 : Project Area Map

NWC Bulverde/1604 SAWS Extension PN: 11134-40

Bexar County, Texas

Cultural Resources Report

December 2019 


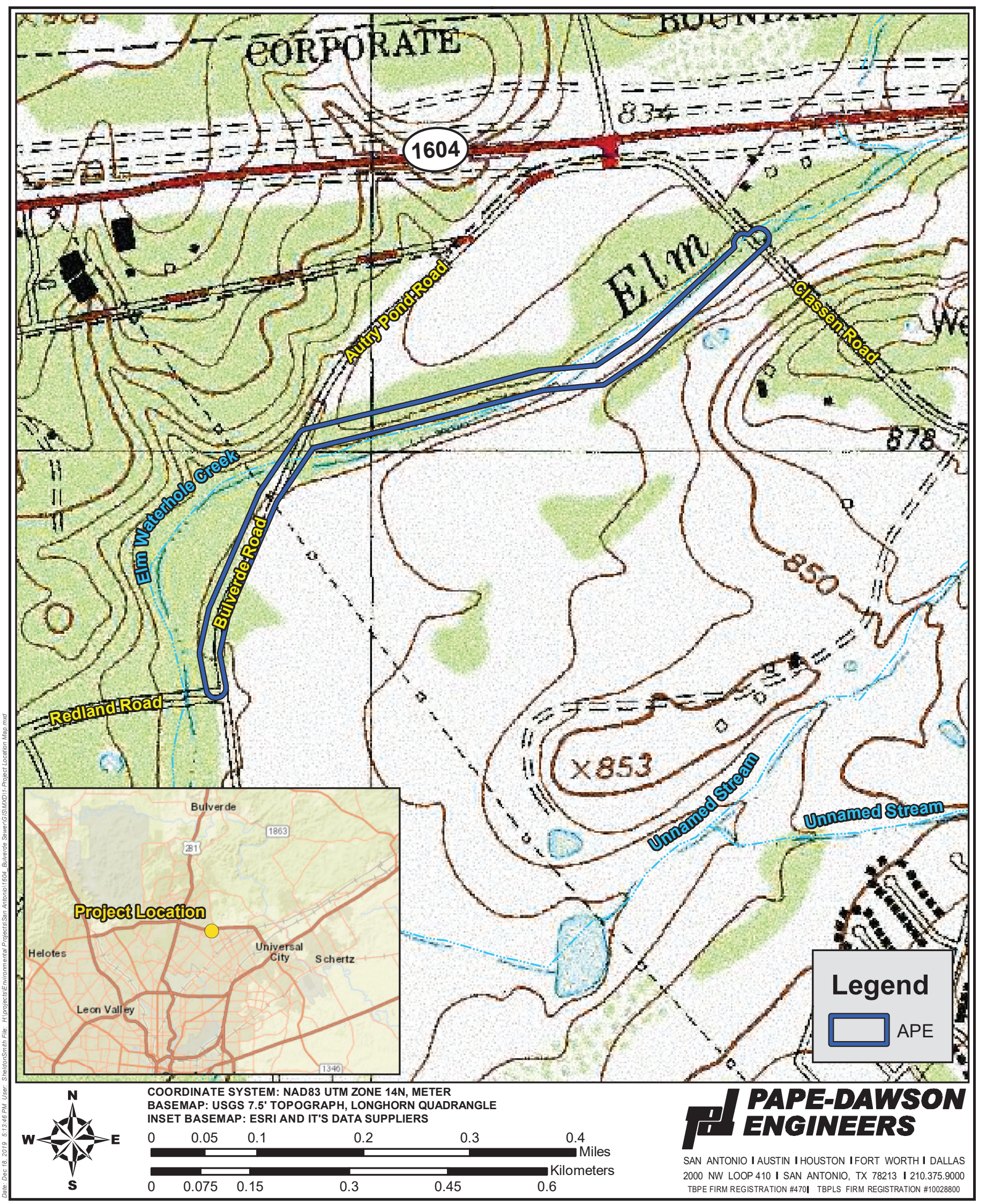

Figure 2 : Project Location Map

NWC Bulverde/1604 SAWS Extension PN: 11134-40 Bexar County, Texas

Cultural Resources Report

December 2019 


\section{Project Setting}

The project is situated $0.32 \mathrm{~km}$ ( 0.2 mile) south of the intersection of Bulverde Road with North Loop 1604 in northern San Antonio (see Figure 2). A review of historic and modern aerials ranging in date from 1955 to 2012 indicates that the APE and surrounding area has been undeveloped and partially wooded pasture land at least as early as 1955, and that Classen Road and Bulverde Road were constructed sometime prior to 1955 (National Environmental Title Research [NETR] Online 2011).

Located in the Edwards Plateau-Balcones Canyonlands regions of central Texas (Wermund 1996), the project landscape is characterized by gently to moderately sloping upland terrain. Elm Waterhole Creek flows westerly crossing through the APE roughly $0.36 \mathrm{~km}$ ( 0.23 mile) from the northern terminus of the APE at Classen Road. The majority of the APE is geologically mapped as late Pleistocene-age Fluviatile terrace deposits (Qt) of gravel, sand and silty clay. A smaller section is mapped as Upper Cretaceous-age Pecan Gap Chalk (Kpg), which is light yellowish brown chalk or chalky marl that weathers to form moderately deep soils (USGS 2005).

Three soil units are mapped within the APE (Figure 3). Patrick soils ( $\mathrm{PaB}$ ) with 1 to 3 percent slopes that are rarely flooded make up more than 76 percent of the APE. These soils are typically found on Paleoterraces and originate from a parent material of clayey alluvium of quaternary age derived from mixed sources and/or sandy alluvium of quaternary age derived from mixed sources. These soils are typically well-drained and can contain as much as 55 percent calcium carbonate. A typical profile has 0 to 43 centimeters $(\mathrm{cm})$ ( 0 to 17 inches [in]) of clay loam, followed by 43 to $152 \mathrm{~cm}$ (17 to $60 \mathrm{in}$ ) of very gravely sand. Nearly 22 percent of the APE is Eckrant cobbly clay (TaB) with 1 to 8 percent slopes. This soil type is typically found on ridges and is derived from a parent material of residuum weathered from limestone. Eckrant cobbly clay is also well-drained and can contain up to 10 percent calcium carbonate. A typical profile displays 0 to $10 \mathrm{~cm}$ ( 0 to 4 in) of cobbly clay, overlying 10 to $28 \mathrm{~cm}$ (4 to $11 \mathrm{in}$ ) of very cobbly clay, and 28 to $203 \mathrm{~cm}$ (11 to $80 \mathrm{in}$ ) of bedrock. Lewisville silty clay (LvA) with 0 to 1 percent slopes comprises the remaining 2 percent of the APE. These soils are typically found on stream terraces and derive from a parent material of calcareous clayey alluvium derived from mudstone. They are well-drained and a profile can contain as much as 40 percent calcium carbonate. A typical profile has 0 to $43 \mathrm{~cm}$ ( 0 to 17 in) silty clay, 43 to $112 \mathrm{~cm}$ (17 to 44 in) silty clay, 112 to $155 \mathrm{~cm}$ (44 to 61 in) silty clay (NRCS 2017). 


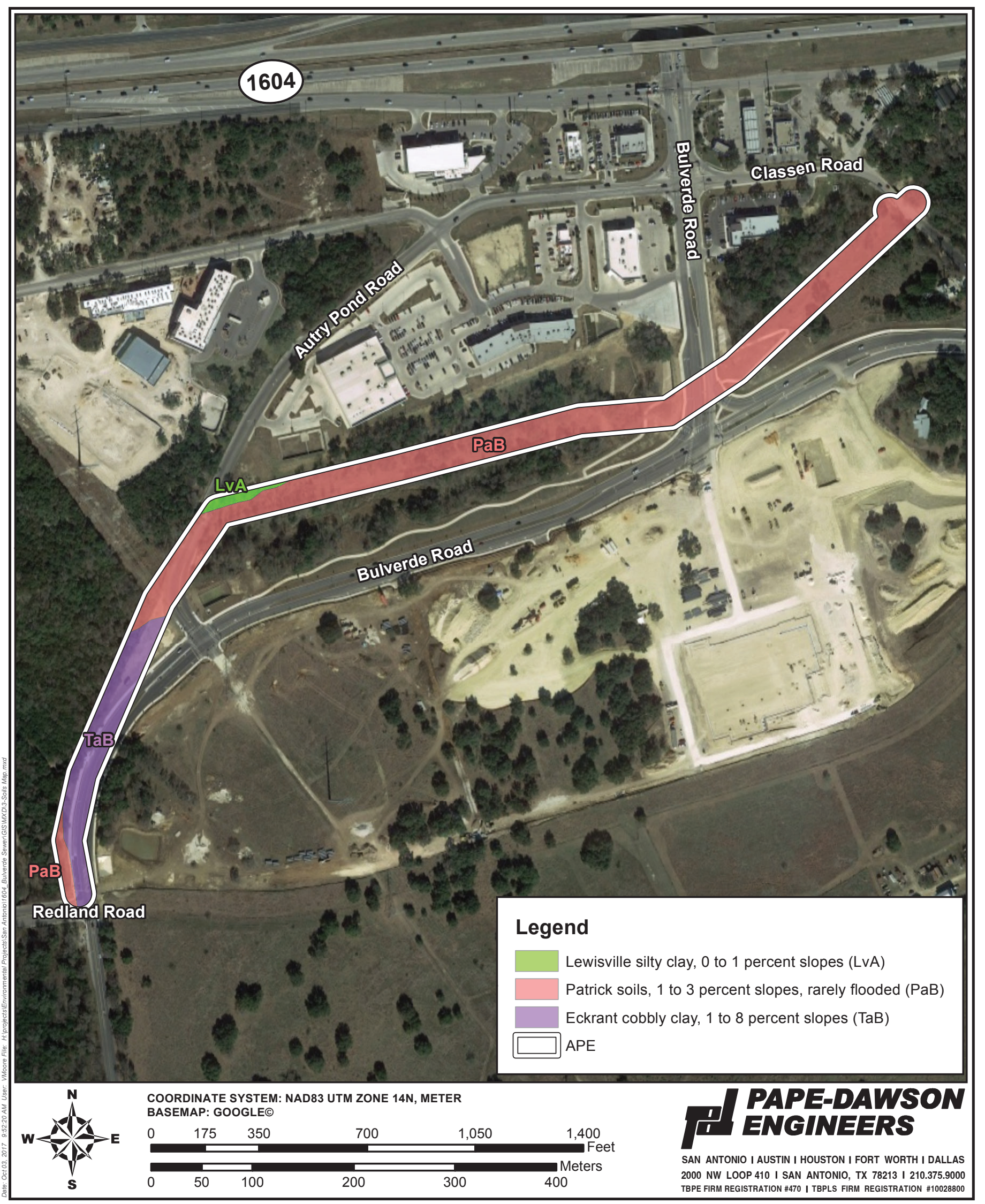

Figure 3 : Soils Map

NWC Bulverde/1604 SAWS Extension PN: 11134-40

Bexar County, Texas

Cultural Resources Report

October 2017 


\section{Cultural Chronology}

Bexar County falls within the Central Texas archaeological region of the Central and Southern Planning Region as delineated by the THC (Mercado-Allinger et al, 1996). Cultural developments in this region are typically classified by archaeologists according to four primary chronological time periods: Paleoindian, Archaic, Late Prehistoric, and Historic. These classifications have been defined primarily by changes in material culture and subsistence strategies over time as evidenced through information and artifacts recovered from archaeological sites. This cultural chronology provides a brief summary of each major cultural period with reference to significant archaeological work that has occurred within the region.

\section{Paleoindian (11,500 B.P. - 8,800 B.P.)}

Although there is some debate about whether pre-Clovis Paleoindian peoples lived in Texas, there is evidence of Paleoindian occupation within Texas by 11,500 B.P. Collins $(1995: 376,381)$ has proposed dividing this period into early and late phases, with Dalton, San Patrice, and Plainview possibly providing the transition between them. Research has shown Paleoindians were gathering wild plants and hunting large mammals (mammoth, bison, etc.) as well as smaller terrestrial and aquatic animals (Collins 1995: 381; Bousman et al. 2004: 75). Projectile points characteristic of the Paleoindian period in Central Texas are lanceolate-shaped and include Clovis, Plainview, and Folsom (Turner and Hester 1993). In Texas, most Paleoindian sites are classified as procurement or consumption sites (Bousman et al. 2004: 76-78), but a few, such as the Wilson-Leonard site in Williamson County (Collins 1995) and the Pavo Real site in Bexar County (Henderson 1980; Collins et al. 2003; Figueroa and Frederick 2008), have produced burials in context (Collins 1995: 383). Other Paleoindian sites discovered within Bexar County include site $41 \mathrm{BX} 47$ on Leon Creek (Tennis 1996), the Richard Beene site (41BX831) (Thoms et al. 2005; Thoms and Mandel 2007), and the St. Mary's Hall site (41BX229), which has provided insight into a more diverse diet for Paleoindian groups (Hester 1978).

As the climate warmed, the Paleoindian people began to shift away from hunting large animals. The changing environment, which led to extinction of the megafauna, likely influenced their decision to focus more on hunting small game animals, including deer and rabbit, as well as gathering edible roots, nuts, and fruits (Black 1989). This change in food supply, as well as a different set of stone tools, marks the transition into the Archaic Period.

Archaic (8,800 B.P. - 1,200 B.P.)

Usually divided into early, middle, late, and sometimes transitional sub-periods, the Archaic marks a gradual shift from hunting Megafauna and some smaller animals supplemented with wild plants to a focus on hunting and gathering medium and small animals and wild plants, and an eventual transition to agriculture. Beginning with Clear Fork gouges and Guadalupe bifaces in the Early Archaic (8500 B.P. - 6000 B.P.) (Turner and Hester 1993; Collins 1995), Early Archaic people produced a variety of point types. The variety of points and their scattered distribution over a large area in the Early Archaic may indicate smaller groups of people moving over larger territories (Prewitt 1981). Point types transition to Bell-Andice-Calf 
Creek, Taylor, and Nolan-Travis points in the Middle Archaic (6000 b.p. -4000 b.p.) (Turner and Hester 1993; Collins 1995), and burned rock middens become an important characteristic. The Middle Archaic focus on constructing burned rock ovens to cook a diverse array of plant food (Black 1989) suggests a slightly more sedentary focus. The Bulverde, Pedernales, Ensor, Frio, and Marcos points in the Late Archaic (4000 b.p. -1300 b.p.) (Turner and Hester 1993; Collins 1995) mirror the diversity of point types found in the Early Archaic. During the Late Archaic, cemeteries, especially associated with rock shelters, become common in central Texas (Dockall et al. 2006). In Bexar County, sites with Early Archaic components include the Housman Road site (41BX47), the Richard Beene site (41BX831) (Thoms et al. 2005; Thoms and Mandel 2007), the Higgins site (41BX184) (Black et al. 1998), and the Panther Springs site (41BX228) (Black and McGraw 1985). While the Elm Waterhole site (41BX300) is representative of a Middle Archaic site within Bexar County (McNatt et al. 2000), the Granberg site (41BX17\41BX271) in San Antonio is a multi-component site with occupations from both the Middle and Late Archaic sub-periods.

Late Prehistoric (1,200 B.P. - 250 B.P.)

As the Archaic transitioned into the Late Prehistoric period, several technological changes become apparent. The most notable change is the use of the bow and arrow rather than the spear and atlatl, as evidenced by smaller projectile points. Another significant innovation is the creation and use of ceramic vessels. Some groups began to practice consistent agriculture during this time as well; there is some evidence that peoples in Central Texas may have incorporated agriculture into their lives, but primarily remained hunter gatherers (Collins 1995). Also during this period, there are possible indications of major population movements, changes in settlement patterns, and perhaps lower population densities (Black 1989). Archaeologists divide the Late Prehistoric into two phases: the Austin, followed by the Toyah phase. The Austin phase is characterized by some of the earliest arrow points, the Scallorn and Edwards types, while the Perdiz-type arrow point and bone-tempered ceramics represent the Toyah phase (Prewitt 1981). Cemeteries become more common in the Late Prehistoric period.

Historic (1600s - 1960)

While there is an overlap between the prehistoric and historic periods (sometimes called the protohistoric), Europeans did not begin exploration in the area until the seventeenth century. Alonso de León's 1689 and 1690 expeditions and Domingo Terán de los Ríos' 1691 expedition were likely the some of the first interactions between Europeans and Native groups (de la Teja 1995:6). According to historical accounts of the expeditions, these early Spanish explorers encountered numerous indigenous groups residing in and near Central Texas (Mercado-Allinger et al. 1996). These indigenous groups likely included the Payaya and the Pamaya who resided in the southern plains of Texas as well as the Tonkawa, Karankawa, Lipan Apache, and Comanche, who entered the area from the northern plains in pursuit of food and stopped at the areas springs (Long 2017). In 1691, Spanish explorers traveling through Bexar County began creating what would become the El Camino Real de los Tejas (The King's Highway, also known as the Old San Antonio Road in portions) (United States Department of the Interior [DOI] 2011). 
This network of roadways at least in part likely followed existing trails already well established by the numerous highly mobile indigenous groups within the area.

These explorations helped the Spanish choose locations to establish five missions in and around what would later become San Antonio. Don Martín de Alarcón established the first mission, San Antonio de Valero, in 1718, on the west bank of the San Pedro Creek, followed by the Presidio San Antonio de Béxar and the Villa de Béxar (de la Teja 1995). However, by 1722 the Marqués de San Miguel de Aguayo had moved the presidio and villa to the west side of the San Antonio River (Clark et al. 1975). Other missions, including Mission San José y San Miguel de Aguayo, Nuestra Señora de la Purísma Concepción, San Juan Capistrano, and San Francisco de la Espada were established in the area from 1718 to 1731 (Clark et al. 1975; Wright 2016). Most of the Native American groups recruited to live at these missions comprised many different groups (Campbell 1977), but it is difficult to know all the groups that were present due to the variations in spelling and phonetic complexity. The missions used this Native labor force to construct acequias, or irrigation ditches, which helped them to develop self-sustaining communities bordered by farmland. (Long 2017). During this period of early settlement, water was an essential component for successful settlement and survival. The acequia system, begun with the arrival of the missionaries, continued to expand to serve irrigation and drinking water needs. The acequia system influenced the street layout in the city (Cox 2005:20) and played an integral part in contact between the Spanish, who brought the engineering concepts for the system, and the indigenous groups forced to provide the construction labor.

In 1731, Spain sent 16 families from the Canary Islands to the villa de Béxar to establish the secular village. With the arrival of these families, surveyors set out the city's main plaza, or Plaza de las Islas, next to the church, designated a spot for the Casas Reales, and began to establish residential lots (Spell 1962). This began San Antonio's gradual secularization. In 1773, San Antonio de Béxar Presidio was named the capital of Spanish Texas, and the settlement including mission Indians had a population of about 2,000 by 1778 (Fehrenbach 2010).

During the 1820 s and early 1830 s, American settlers began moving to San Antonio in increasing numbers, though the population remained predominately Mexican. In 1824, Texas and Coahuila were united into a single state with the capital at Saltillo. San Antonio fought for Mexican Independence in 1813, then for its own sovereignty during the Texas Revolution. The Siege of Bexar and the Battle of the Alamo, in 1835 and 1836, were both located within San Antonio, showing its importance in the region. After Texas gained its independence from Mexico in 1836, Bexar County was created and San Antonio was chartered as its seat (Long 2017). However, this was not the end of conflict in the city; a dispute with Comanche Indians resulted in the Council House Fight in 1840, and Woll's invasion in 1842 precipitated Texas' entrance into the United States as the 28th state. By 1846, San Antonio's population had decreased to approximately 800 people (Fehrenbach 2017).

On March 2, 1861, Texas seceded from the Union and soon after the Civil War began. San Antonio became a Confederate storage area as well as a location where military units could be organized; however, the 
city kept its distance from most of the actual fighting (Fehrenbach 2017). After the Civil War, the population in Bexar County continued to grow larger, spurred on by the arrival of the railroad in 1877 (Fehrenbach 2017). Industries such as cattle, distribution, ranching, mercantile, gas, oil, and military centers in San Antonio prospered. The city served as the distribution point for the Mexico-United States border as well as the rest of the southwest. At the turn of the twentieth century, San Antonio was the largest city in Texas with a population of more than 53,000. Much of the city's growth after the Civil War was a result of an influx of southerners fleeing the decimated, reconstruction-era south. An additional population increase came after 1910, when large numbers of Mexicans began moving into Texas to escape the Mexican Revolution (Fehrenbach 2017).

Modernization in San Antonio increased dramatically between the 1880 s and the 1890 s, compared to the rest of the United States. Civic government, utilities, electric lights and street railways, street paving and maintenance, water supply, telephones, hospitals, and a city power plant were all built or planned around this time (Fehrenbach 2017). The First United States Volunteer Cavalry was organized in San Antonio during the Spanish-American War, and San Antonio was an important military center for the army and air forces during both world wars. Its five military bases provided an important economic base and contributed to the evolution of the city's medical research industry.

In 1921, a disastrous flood engulfed downtown San Antonio with up to $12 \mathrm{ft}$ ( $3.7 \mathrm{~m}$ ) of water. The Olmos Dam was built in response to this event to prevent further flooding. Sections of the San Antonio River were straightened and widened in areas to control the water flow. Another recommendation was to construct an underground channel in downtown San Antonio and to cover portions of the river with concrete. This last idea was controversial, but a compromise was eventually agreed upon to create a Riverwalk with shops and restaurants along the water channel, which was completed in 1941 (Fisher 2014).

\section{Methods}

\section{Records Review}

Prior to fieldwork, Pape-Dawson archaeologists conducted a thorough background literature and records search of the proposed APE. This research included reviewing the Longhorn (2998-422) U.S. Geologic Survey (USGS) 7.5-minute topographic quadrangle map at the Texas Archeological Research Laboratory (TARL) and searching the THC's Texas Archeological Sites Atlas (THC 2017) online database (Atlas) for any previously recorded surveys and historic or prehistoric archaeological sites located within a 1-km (0.62mile) radius of the APE. The review also included information on the following types of cultural resources located within the 1-km (0.62-mile) study area: NRHP-listed properties, sites, and districts, SALs, Official Texas Historical Markers (OTHM), Recorded Texas Historic Landmarks (RTHL), and cemeteries. The City of San Antonio's Historic Landmark Sites and Historic Districts GeoDatabases were also consulted. The archaeologists also examined U.S. Department of Agriculture (USDA) Soil Survey of Bexar County (Taylor 
et al. 1991), Natural Resources Conservation Service (NRCS) Web Soil Survey, the Geologic Atlas of TexasSan Antonio Sheet (BEG 1983), and historic maps and aerials that depict the APE.

As a part of the review, a Pape-Dawson archaeologist examined the Texas Department of Transportation (TxDOT) Historic Overlay, a mapping/GIS system with historic maps and resource information covering most portions of the state (Foster et al. 2006). In addition to this source, historic and modern aerial photographs (Nationwide Environmental Title Research Online [NETR Online] 2017) were reviewed to identify Historic High Probability Areas (HHPAs).

\section{Archaeological Fieldwork}

Pape-Dawson archaeologists conducted an intensive archaeological survey of the proposed 3.7-ha (9.18acre linear APE. Survey methods followed the Council of Texas Archeologists' Archeological Survey Standards for Texas. This investigation consisted of pedestrian survey along the $30-\mathrm{m}$ (100-ft)-wide easement with inspection of the ground surface, augmented by shovel testing in areas with the perceived potential for buried cultural deposits and with less than 30 percent ground surface visibility. As soils in the project area are clayey upland deposits, it was anticipated that archaeological deposits, if present, would be shallowly buried or on the ground surface and visible to surface inspection.

A total of 16 shovel tests were excavated to investigate the $1.2 \mathrm{~km}$ (.75 mile) sewer line, exceeding the state's minimum standard of 1 shovel test every $100 \mathrm{~m}$ or 16 shovel tests per 1 linear mile. Shovel tests were roughly $30 \mathrm{~cm}$ (11.8 in) in diameter and were excavated in 10-cm (4-in) levels to sterile clay, bedrock, or to a maximum of $80 \mathrm{~cm}$ ( $31.5 \mathrm{in}$ ) below the ground surface when intact soils were encountered. All soils were screened through $0.64-\mathrm{cm}(0.25-\mathrm{in})$ wire mesh unless clay concentrations were high enough to require hand sorting. All shovel tests were recorded, visually described, plotted by a Global Positioning System (GPS) unit, and backfilled upon completion.

Site 41BX1786 was revisited during the current field effort. However, no artifacts were recovered or collected. A State of Texas Archeological Site Revisit Form was filled out and submitted to TARL. The site was evaluated according to the criteria in Title 36 Code of Federal Regulations Part 60.4 (36 CFR 60.4) and in 13 Texas Administrative Code 26.10 (13 TAC 26.10). Project records and photographs will be curated at the Center for Archeological Research (CAR) at the University of Texas at San Antonio following their specific standards of preparation.

\section{Results}

\section{Records Review}

The background review determined that there are no NRHP-listed properties or districts, SALs, OTHMs, RHTLs, cemeteries, or local historic landmarks within $1 \mathrm{~km}$ (0.62 mile) of the APE; however, in addition to 41BX1786, fourteen archaeological sites (41BX66, 41BX68, 41BX901, 41BX903, 41BX904, 41BX905, 
41BX906, 41BX907, 41BX909, 41BX913, 41BX914, 41BX1459, 41BX1625, and 41BX1787) are within $1 \mathrm{~km}$ (0.62 mile) of the APE. In addition, portions of the APE have been previously surveyed by SWCA Environmental Consultants (SWCA) in 2008 and 2015 (Galindo 2008; Acuña 2016) resulting in the recordation of site (41BX1786) which crosses into the APE, and 41BX1787 located adjacent to the APE (Table 1, Figure 4).

Site 41BX1786 is within the current APE, and was documented by SWCA in 2008 during the Bulverde Marketplace survey (Galindo 2008). The site is on the northern terrace above Elm Waterhole Creek and consists of a surficial prehistoric lithic scatter. Cultural materials documented at the site include nondiagnostic lithic debitage, chipped stone tools, and burned rocks. Artifacts were observed on the ground surface in an area measuring $500 \mathrm{~m}(1,640 \mathrm{ft})$ east to west and $250 \mathrm{~m}(820 \mathrm{ft})$ north to south. Based on the lack of temporally diagnostic tools, subsurface deposits, and features and the sparse quantity of surficial artifacts, SWCA recommended no further work for site 41BX1786 (Galindo 2008).

Site 41BX1787 is mapped parallel to the APE southeast of Elm Waterhole Creek and is between 15 and 55 m (49 and $180 \mathrm{ft}$ ) south of the APE. It was documented by SWCA in 2008 during the Bulverde Marketplace survey (Galindo 2008). The site contained a sparse scatter of lithic material including non-diagnostic lithic debitage, chipped stone tools, and burned rocks. Buried artifacts were encountered in 10 of the 20 shovel tests excavated, including one Frio projectile point. No features were encountered and the buried deposits were confined to the upper $35 \mathrm{~cm}$ (14 in). Based on the lack of features and the sparse quantity of artifacts, SWCA recommended no further work for site 41BX1786 (Galindo 2008). 
Table 1. Previously Recorded Archaeological Sites within $1 \mathrm{~km}$ (0.62 mile) of the APE.

\begin{tabular}{|c|c|c|c|c|c|}
\hline $\begin{array}{c}\text { Site } \\
\text { Trinomial }\end{array}$ & Site Type & Age of Deposits & $\begin{array}{l}\text { Depth of } \\
\text { Deposits }\end{array}$ & $\begin{array}{c}\text { Distance and } \\
\text { Direction from } \\
\text { APE }\end{array}$ & $\begin{array}{c}\text { Eligibility per THC } \\
\text { Atlas }\end{array}$ \\
\hline $41 B \times 66$ & Campsite & Prehistoric & Unknown & $364 \mathrm{~m} \mathrm{NE}$ & Ineligible \\
\hline 41BX68 & Quarry & Prehistoric & Unknown & $435 \mathrm{~m} \mathrm{~N}$ & Undetermined \\
\hline 41BX901 & Stone Quarry & $\begin{array}{l}\text { Archaic through } \\
\text { Late Prehistoric }\end{array}$ & $\sim 40 \mathrm{cmbs}$ & $590 \mathrm{~m} \mathrm{~W}$ & Ineligible \\
\hline 41BX903 & $\begin{array}{l}\text { Burned Rock } \\
\text { Midden }\end{array}$ & Archaic & $50+\mathrm{cmbs}$ & $215 \mathrm{~m} \mathrm{~W}$ & Eligible \\
\hline 41BX904 & $\begin{array}{l}\text { Chipping } \\
\text { Station }\end{array}$ & Archaic & $66 \mathrm{cmbs}$ & $425 \mathrm{~m} \mathrm{~W}$ & Not Reported \\
\hline 41BX905 & Quarry & Prehistoric & $20-66 \mathrm{cmbs}$ & $160 \mathrm{~m} \mathrm{~W}$ & Eligible \\
\hline 41BX906 & $\begin{array}{l}\text { Quarry and } \\
\text { Lithic Scatter }\end{array}$ & Prehistoric & $0-20 \mathrm{cmbs}$ & $170 \mathrm{~m} \mathrm{~W}$ & Not Reported \\
\hline 41BX907 & Quarry & Prehistoric & Unknown & $300 \mathrm{~m}$ WSW & Not Reported \\
\hline 41BX909 & Lithic Scatter & Prehistoric & $30-50 \mathrm{cmbs}$ & $200 \mathrm{~m} \mathrm{E}$ & Not Reported \\
\hline 41BX913 & $\begin{array}{c}\text { Caliche Stone } \\
\text { House }\end{array}$ & Historic- ca. 1893 & Unknown & $1000 \mathrm{~m} \mathrm{E}$ & Not Reported \\
\hline 41BX914 & Log House & Historic & Unknown & $580 \mathrm{~m} \mathrm{SE}$ & Not Reported \\
\hline 41BX1459 & Unknown & Unknown & Unknown & $820 \mathrm{~m} \mathrm{~W}$ & Not Reported \\
\hline 41BX1625 & Lithic Scatter & Unknown & Surface & $865 \mathrm{~m} \mathrm{~W}$ & Ineligible \\
\hline 41BX1786 & Lithic Scatter & Prehistoric & Surface & Within & Ineligible \\
\hline 41BX1787 & Lithic Scatter & Prehistoric & $0-30 \mathrm{cmbs}$ & $15 \mathrm{~m}$ south & Ineligible \\
\hline
\end{tabular}


This page has been redacted as

it contains restricted information 


\section{Historic Map Review}

In addition to the cultural resources records review, Pape-Dawson examined recent and historic-age topographic maps $(1993,1986,1981,1975,1968$, and 1959) and aerial photographs $(2012,2010,2008$, $2004,1995,1966,1963$, and 1955) to identify historic-age structures and previous impacts that may have occurred at the project location. Historic topographic map and aerial photograph research (NETR Online var. 2017) identified no historic-age structures within the APE, which has remained undeveloped and partially wooded pasture land from at least 1955 to 2010. Both Bulverde Road (along the re-routed section now called Autry Pond Road) and Classen Road are visible on the 1955 aerial. In addition, a possible pond is visible adjacent to the eastern end of the APE on the 1955 aerial; however, by 1973 it is no longer easily identified and seems to have been filled in. Redlands Road was under construction on the 1986 aerial and the associated Redlands subdivision to the west had been completed by 1995 (NETR Online var. 2017). An existing utility running along Elm Waterhole Creek within the current APE appears to have been constructed sometime prior to December 2003 (Google 2017). Multiple two-tracks are visible on the 2004 aerial crisscrossing the APE. A long flood control dam running diagonally across Elm Waterhole Creek within the APE can be seen on the 2010 aerial image. During the same year, construction in portions of the Bulverde Marketplace north of the APE is evident. Two buried utilities run from the existing utility within the APE through the site 41BX1786 to the Bulverde Marketplace. Construction of the new portion of Bulverde Road first appears on the January 2015 aerial with massive ground disturbance visible within the APE where the road crosses the creek (Google 2017). Sometime prior to the October 2016 aerial, a section of road roughly $140 \mathrm{~m}$ (459 ft) in length was removed just west of the intersection of Autry Pond Road and Bulverde Road leaving a large gravel filled area, and the new section of Bulverde Road from Autry Pond Road south to Redland Road was expanded and sidewalks were added within the APE (Google 2017).

\section{Fieldwork}

Pape-Dawson archaeologists conducted an intensive archaeological survey of the 1.2-km (0.75-mile)-long 30-m (100 ft)-wide APE on September 20, 2017. The archaeological survey consisted of a pedestrian survey with shovel testing (Figure 5). During this survey, one previously recorded site (41BX1786) was revisited within the limits of the APE north of Elm Waterhole Creek. Six shovel tests were excavated within and near the original site boundary. No archaeological material associated with site 41BX1786 was encountered. 
This page has been redacted as

it contains restricted information 
The landscape of the APE consisted of level to gently to moderately sloping upland terraces (Figure 6). Limestone and chert gravels and cobbles were often observed on the surface of the sloping upland landforms north of Elm Waterhole Creek (Figure 7). Elm Waterhole Creek parallels the APE along a northeastern-southwestern axis crossing the APE once just past Bulverde Road. Generally, the channel is rock lined with thick vegetation to either side (Figure 8 ). The western third of the project area runs within and adjacent to Autry Pond and Bulverde Roads (Figure 9). A wetland identified by Pape-Dawson biologist is adjacent to and crossing into portions of the APE. The wetland was observed between Autry Pond and

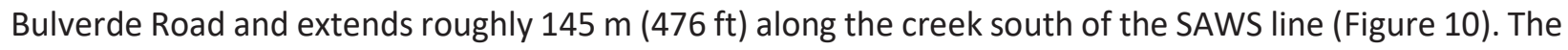
vegetation within the APE largely consisted of medium to tall grasses, cactus, and cat tails (within the wetland). Trees documented within the APE consisted mainly of live oak, mesquite, and Ashe juniper. Ground surface visibility throughout the project area was generally less than 30 percent depending on leaf litter and grasses.

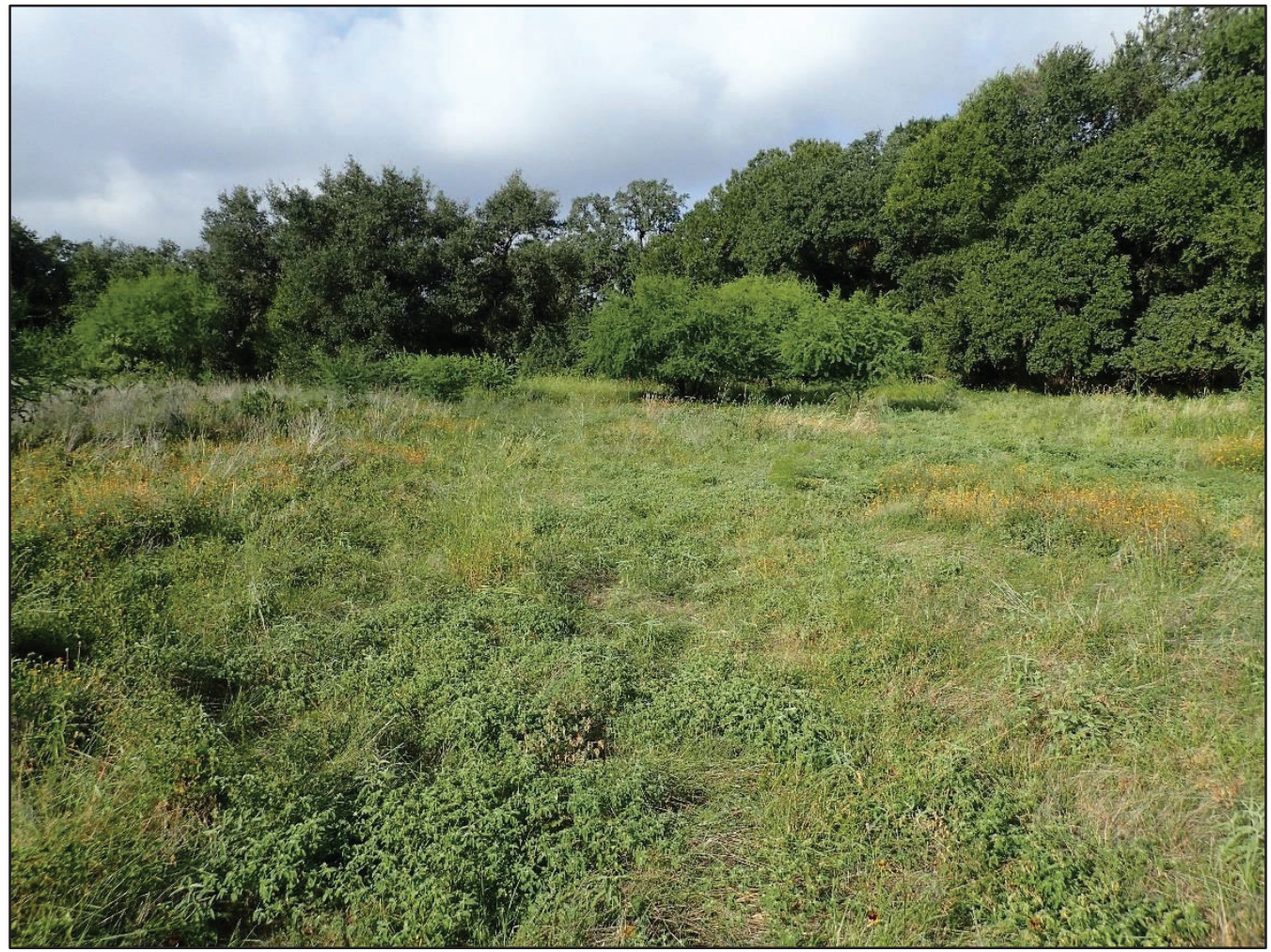

Figure 6. APE west of Classen Road and south of Elm Waterhole Creek, camera facing northwest. 


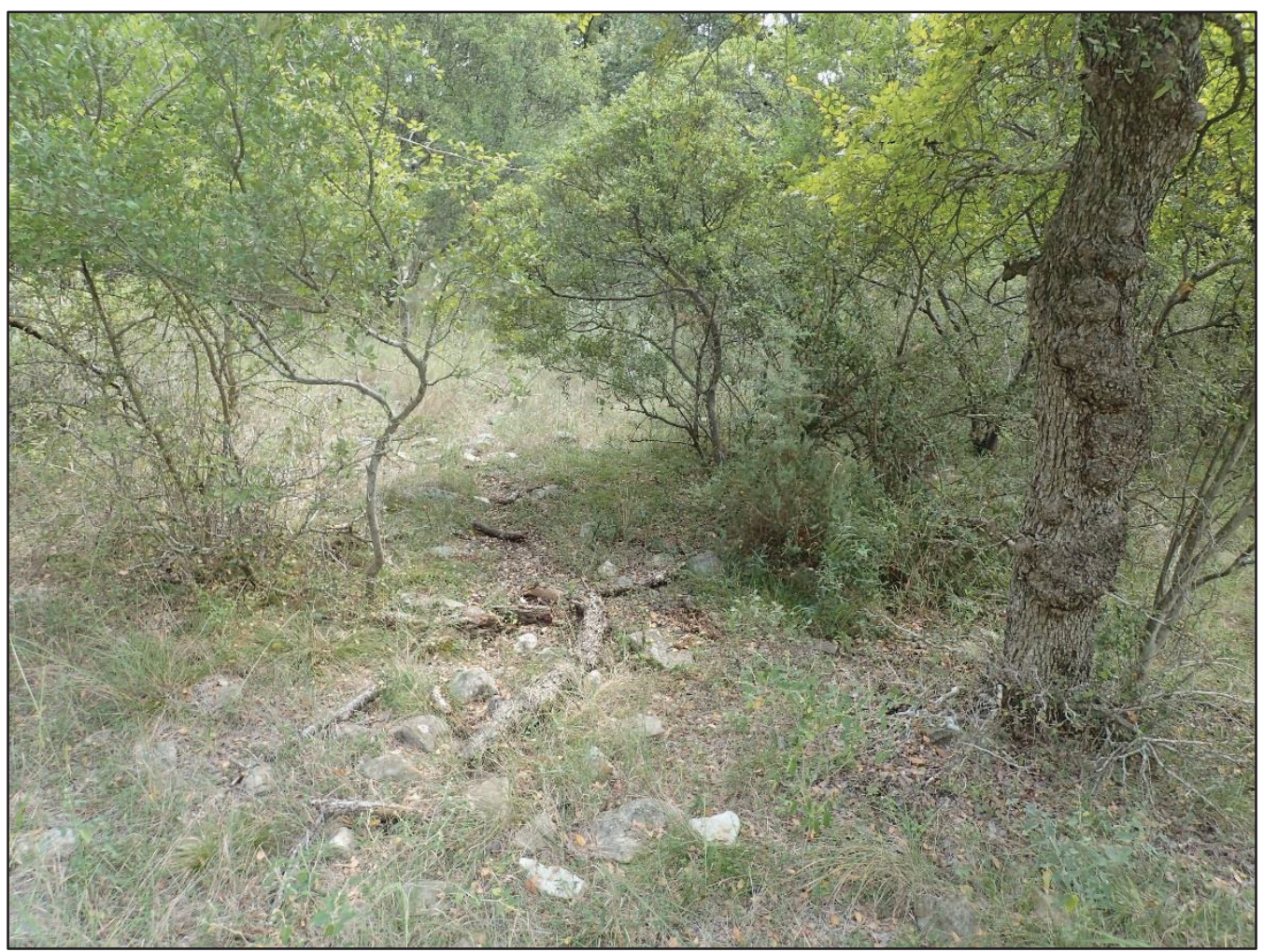

Figure 7. Limestone cobbles on the surface in the APE, camera facing east.

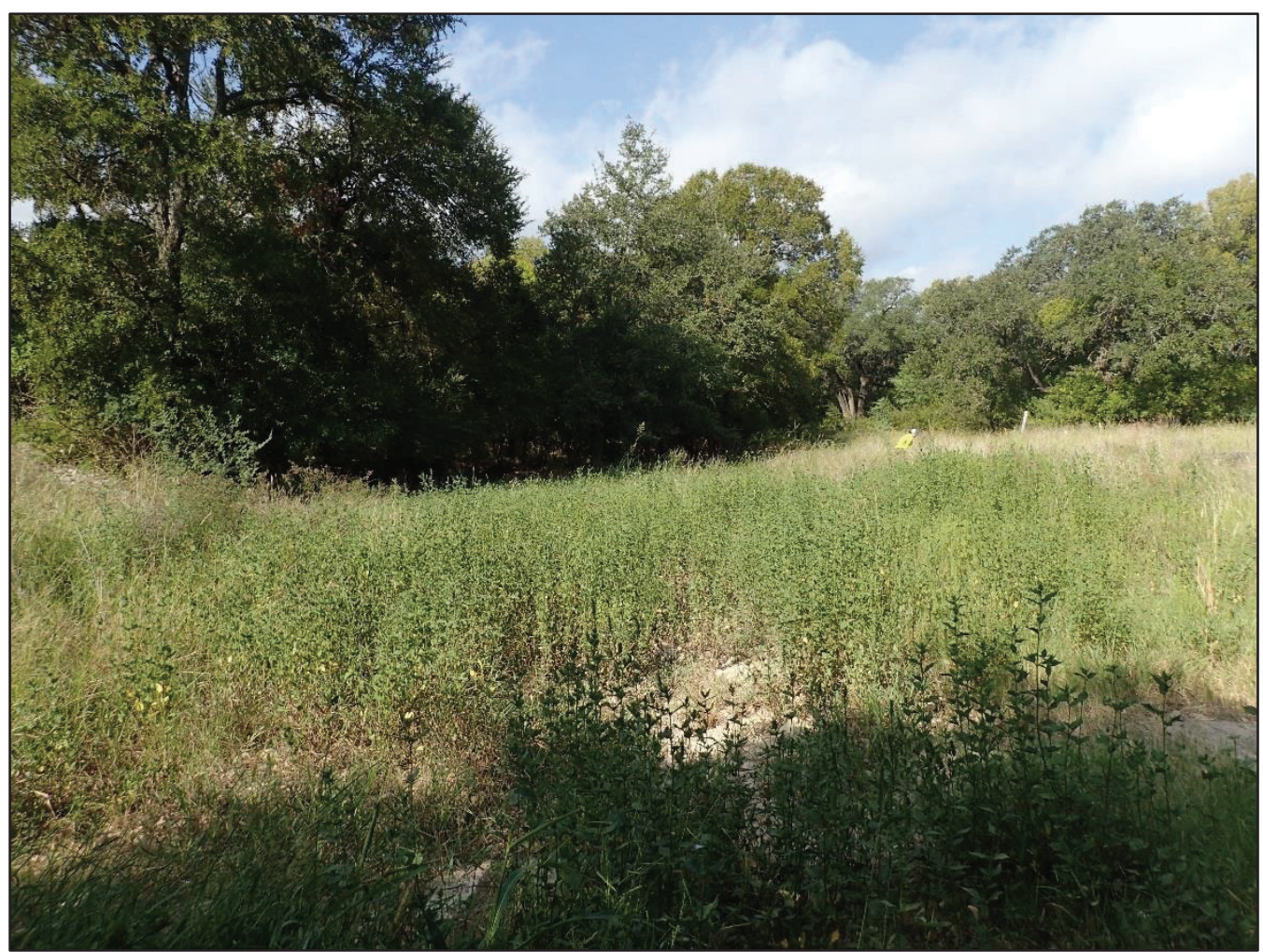

Figure 8. Elm Waterhole Creek channel crossing the APE west of Bulverde Road, camera facing west. 


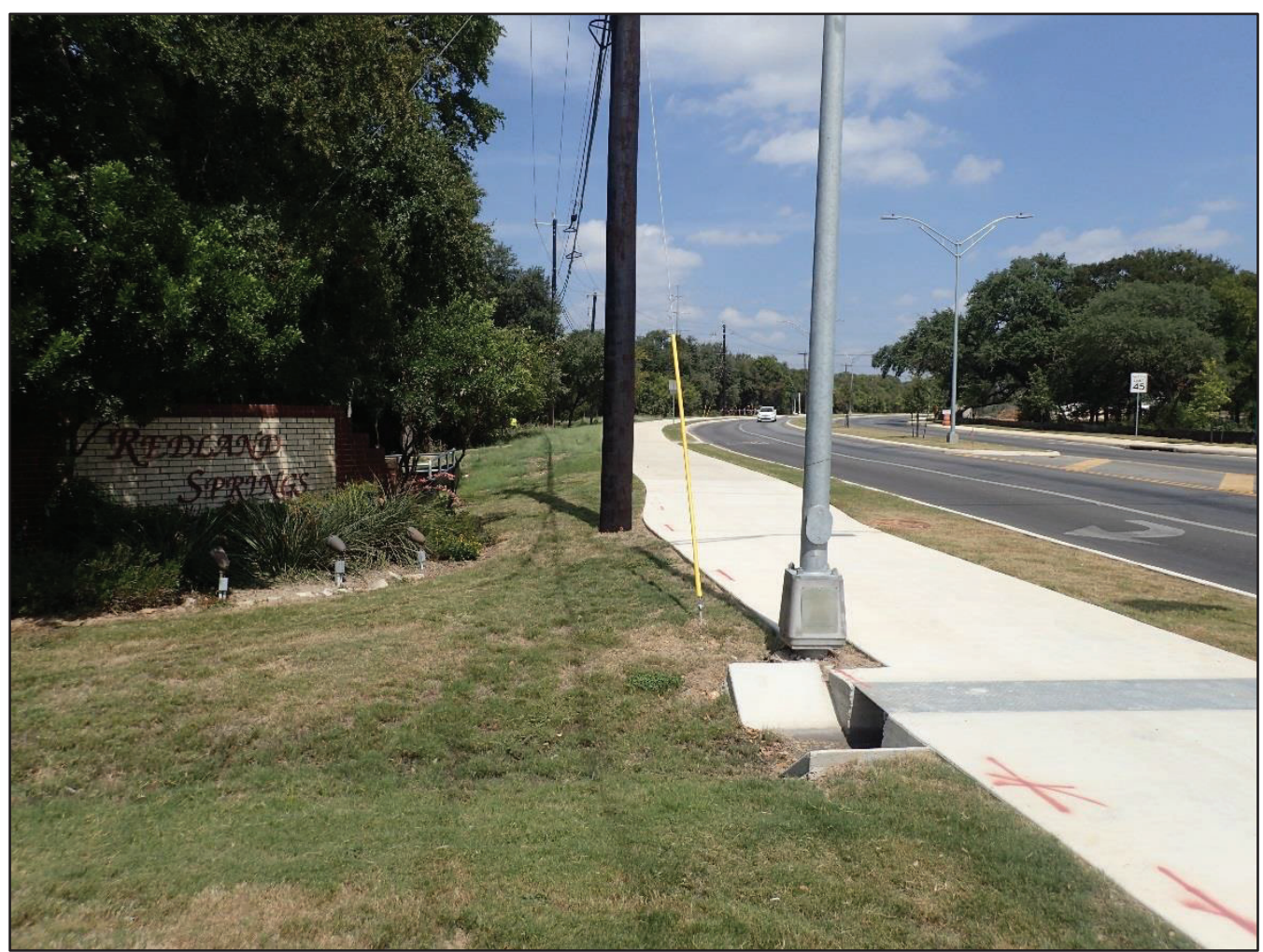

Figure 9. Southwestern end of APE at Redland Road and Bulverde Road, camera facing north.

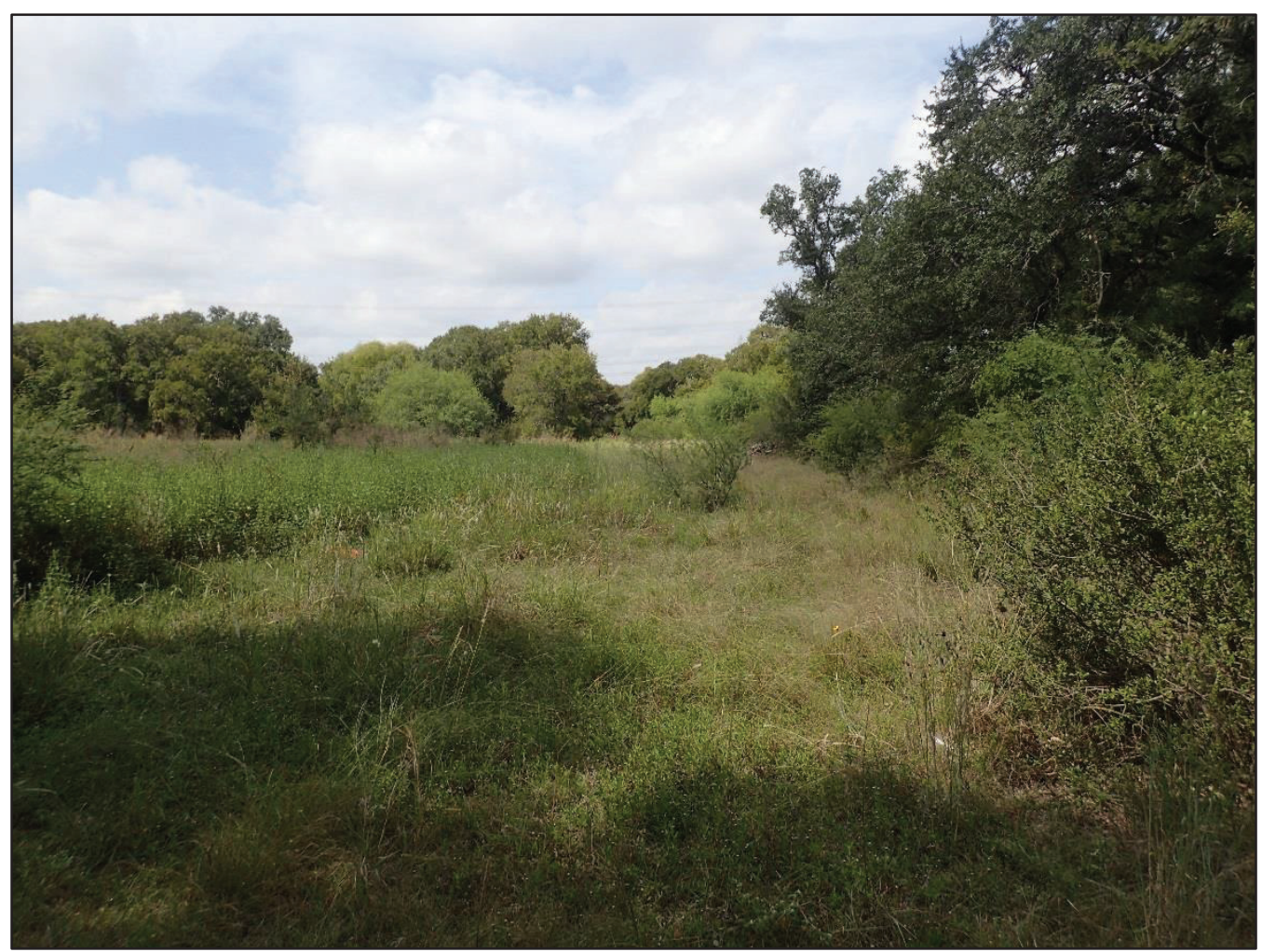

Figure 10. Example of wetlands within the APE, camera facing west. 
The survey found a large portion of the APE to be extensively disturbed. Previous impacts to the APE were photographed and noted as part of the survey effort (Figure 11). Disturbances within the APE have resulted from both natural and artificial impacts. Artificial impacts included the construction of Classen Road, Bulverde Road and Autry Pond Road, multiple existing buried utilities, overhead power-lines, construction of a bridge across the creek at Bulverde Road, and the construction of sidewalks along and under Bulverde Road (Figure 12, Figure 13, and Figure 14). The stretch of the APE running south across Autry Pond Road then along Bulverde to Redland Road shows additional disturbances as evidenced by significant difference in elevation between the adjacent property and the APE. There are also an existing water line, new sidewalk, sprinkler system, and large culvert running under Bulverde road (Figure 15, Figure 16, and Figure 17). Roughly $140 \mathrm{~m}$ (459 ft) of this disturbance is associated with the old route of Bulverde Road (Figure 18) before the intersection at Autry Pond Road and Bulverde Road was constructed. Natural impacts include erosion into Elm Waterhole Creek that parallels and crosses the APE, bioturbation caused primarily by tree fall and animal burrowing, and game trails crisscrossing the APE. Previously, the area was cattle pasture as visible on historic aerials reviewed prior to the survey. 


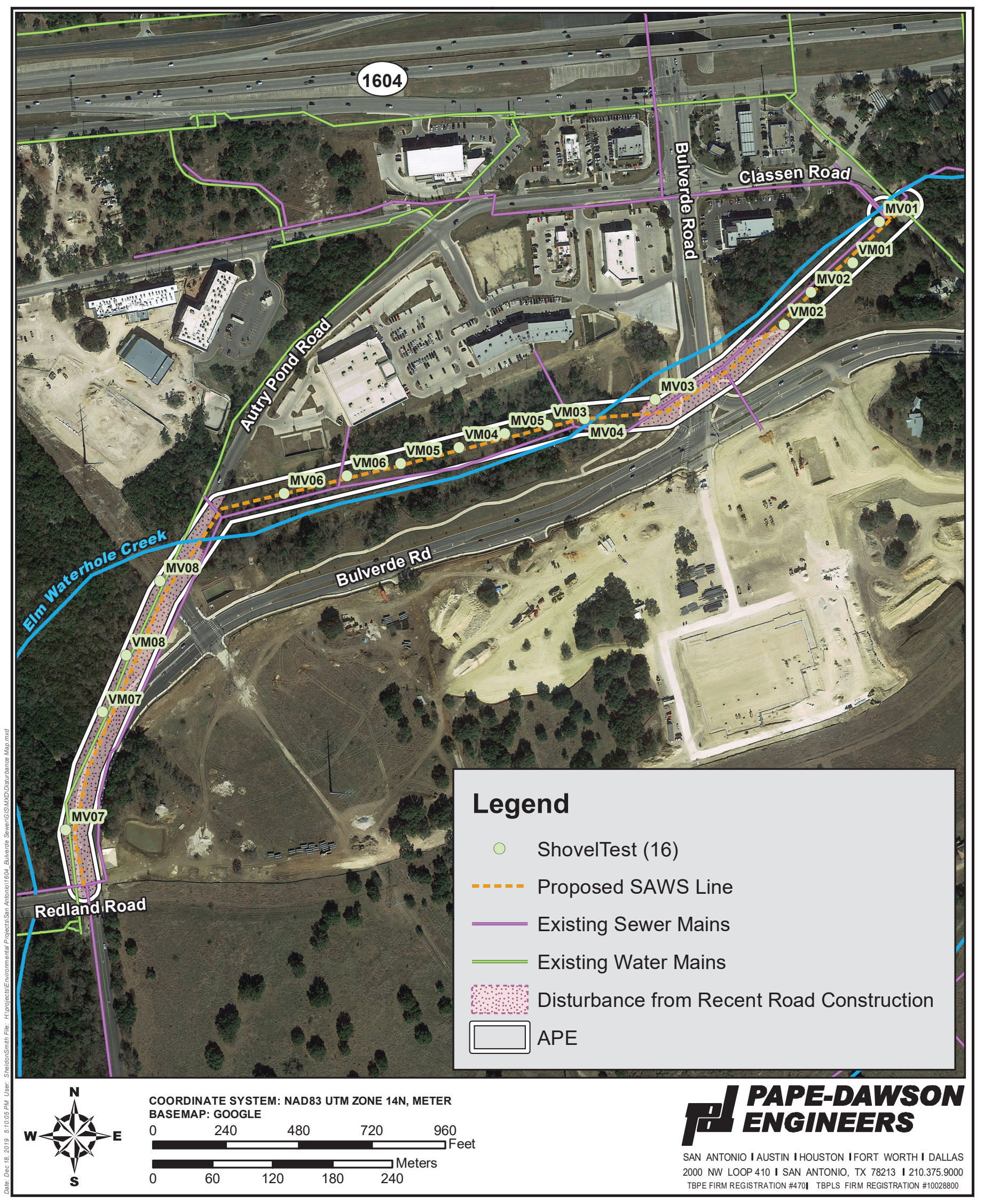

Figure 11. Disturbance Map with Shovel Test Locations

NWC Bulverde/1604 SAWS Extension PN: 11134-40

Bexar County, Texas

Cultural Resources Report

December 2019 


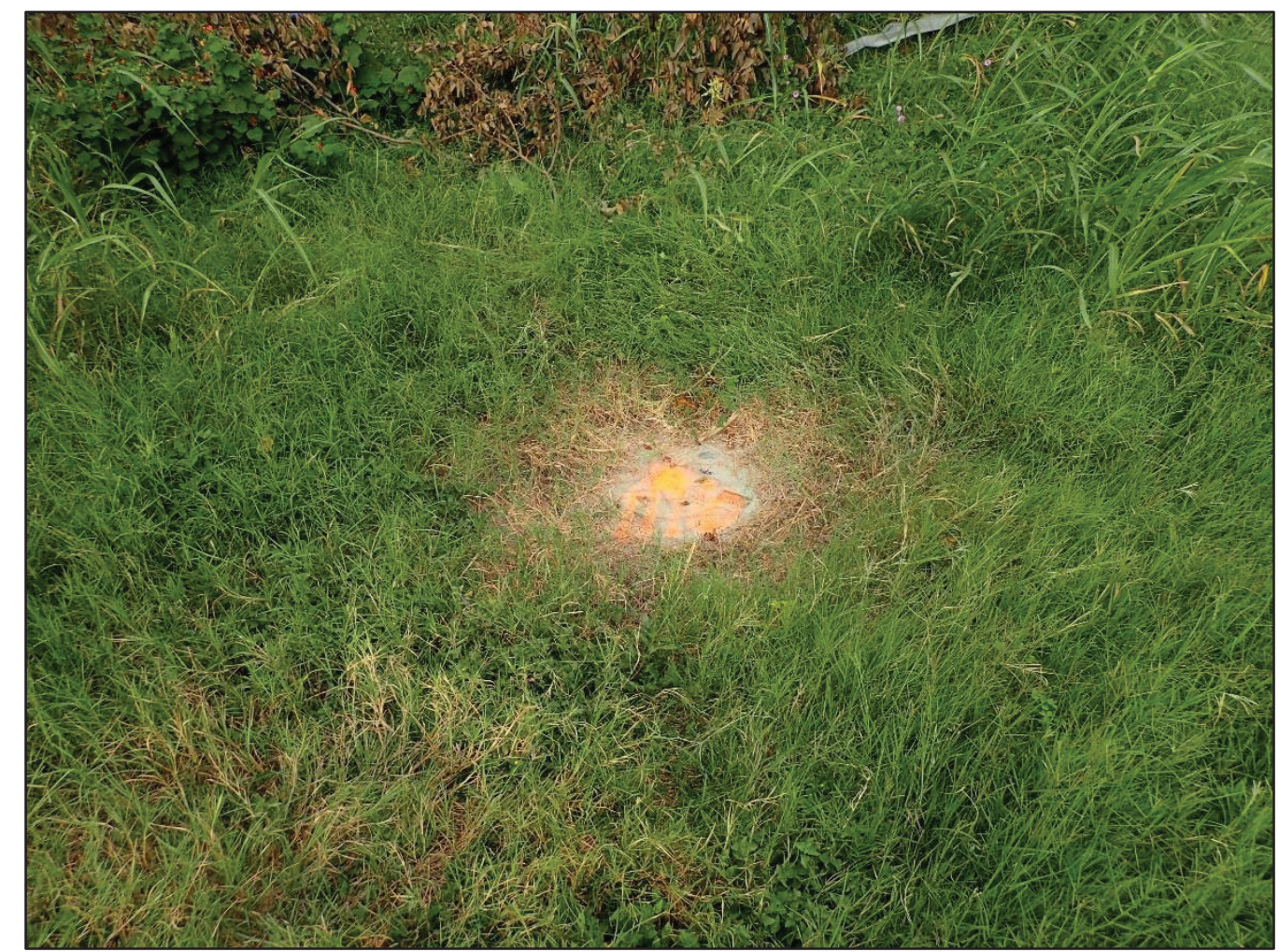

Figure 12. Existing sewer line west of Classen Road in the ROW and APE (runs to the west).

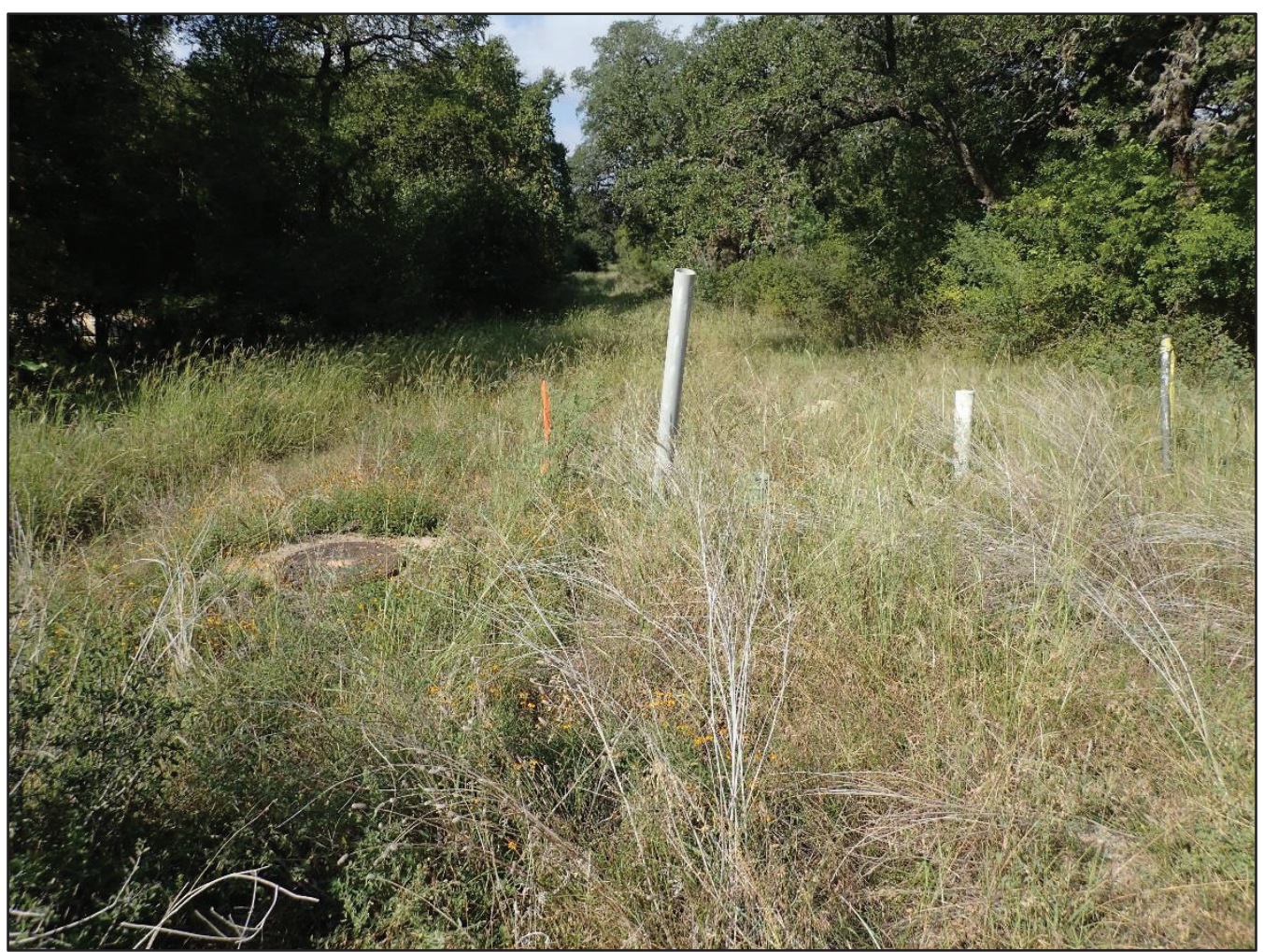

Figure 13. Existing sewer line within the APE, camera facing west. Site $41 \mathrm{BX} 1786$ is in the tree line on the right. 


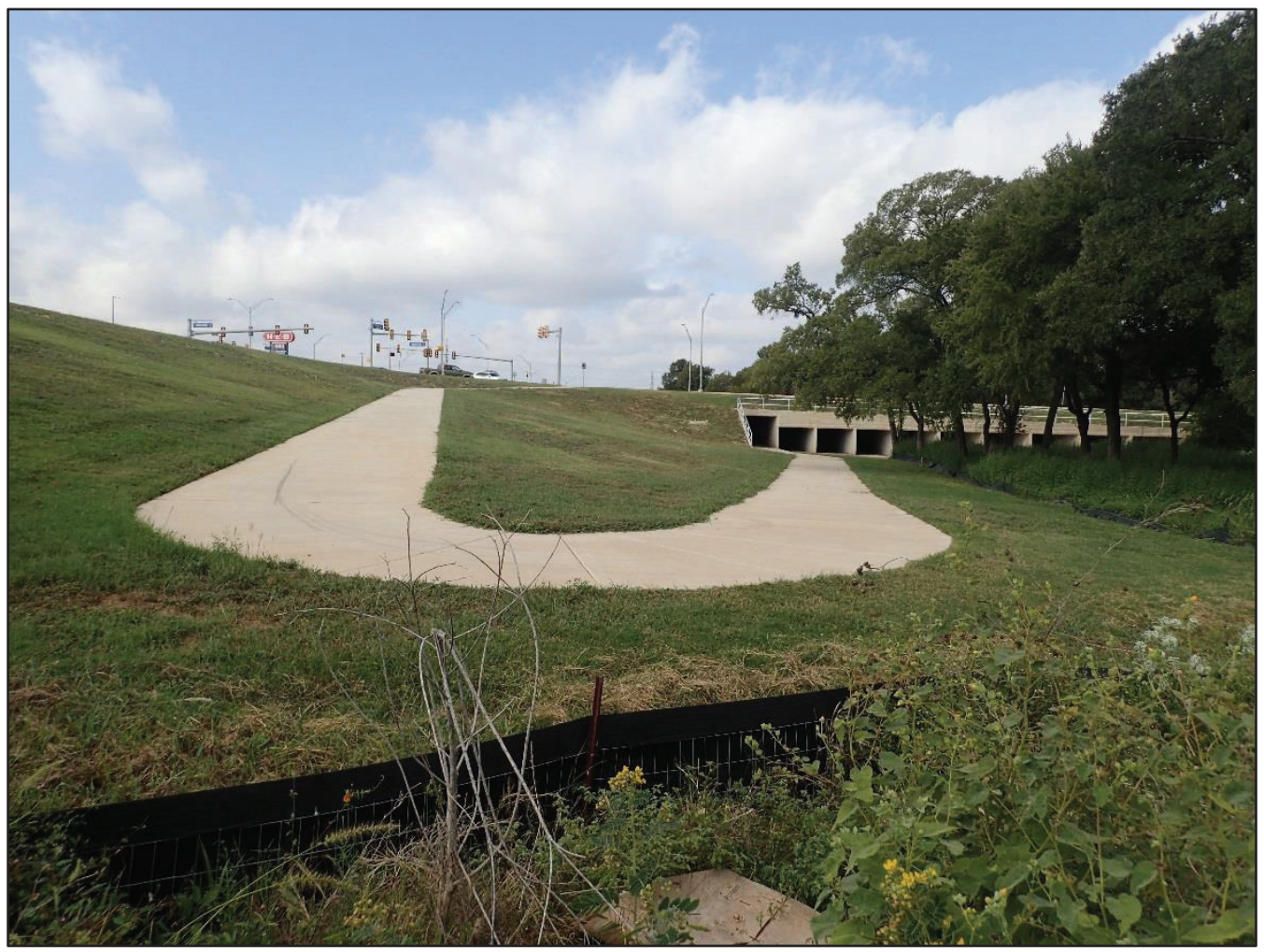

Figure 14. Disturbance associated with the construction of Bulverde Road, and sidewalks within the existing APE, camera facing southwest.

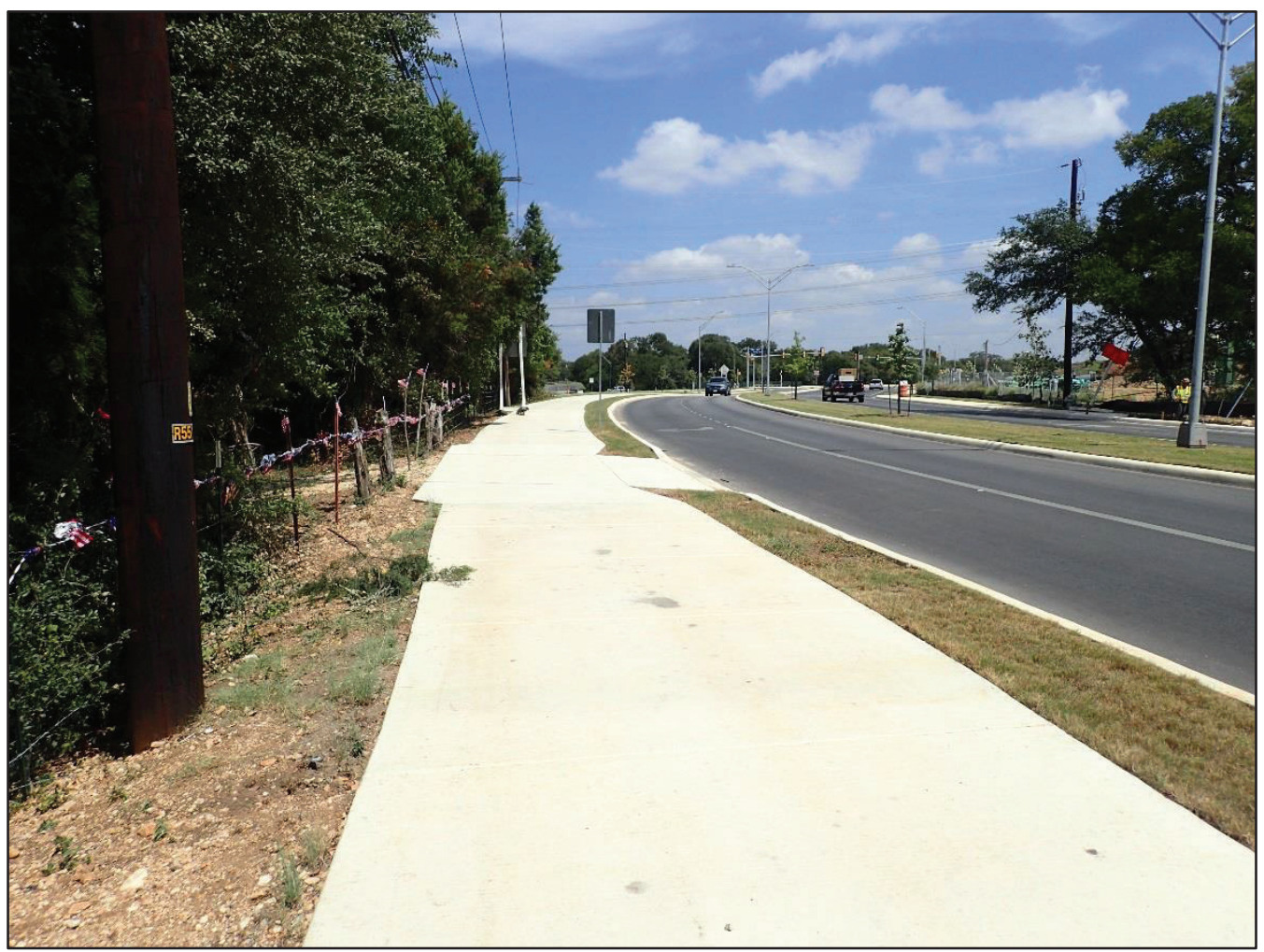

Figure 15. Built up sidewalk area adjacent to Bulverde Road within APE, camera facing northeast. 


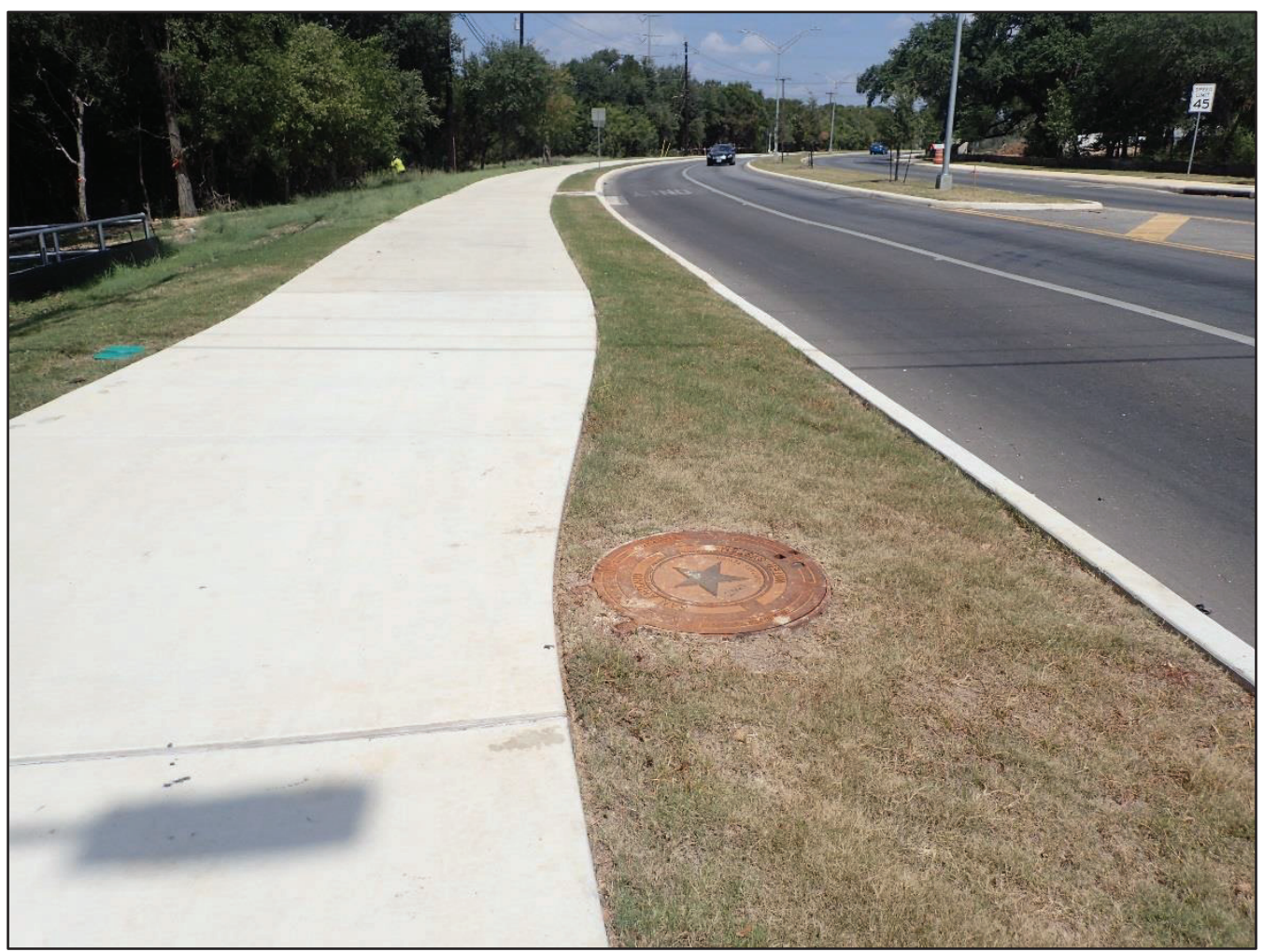

Figure 16. Water Main manhole and sprinkler system access hatch (left center) within the APE, camera facing north.

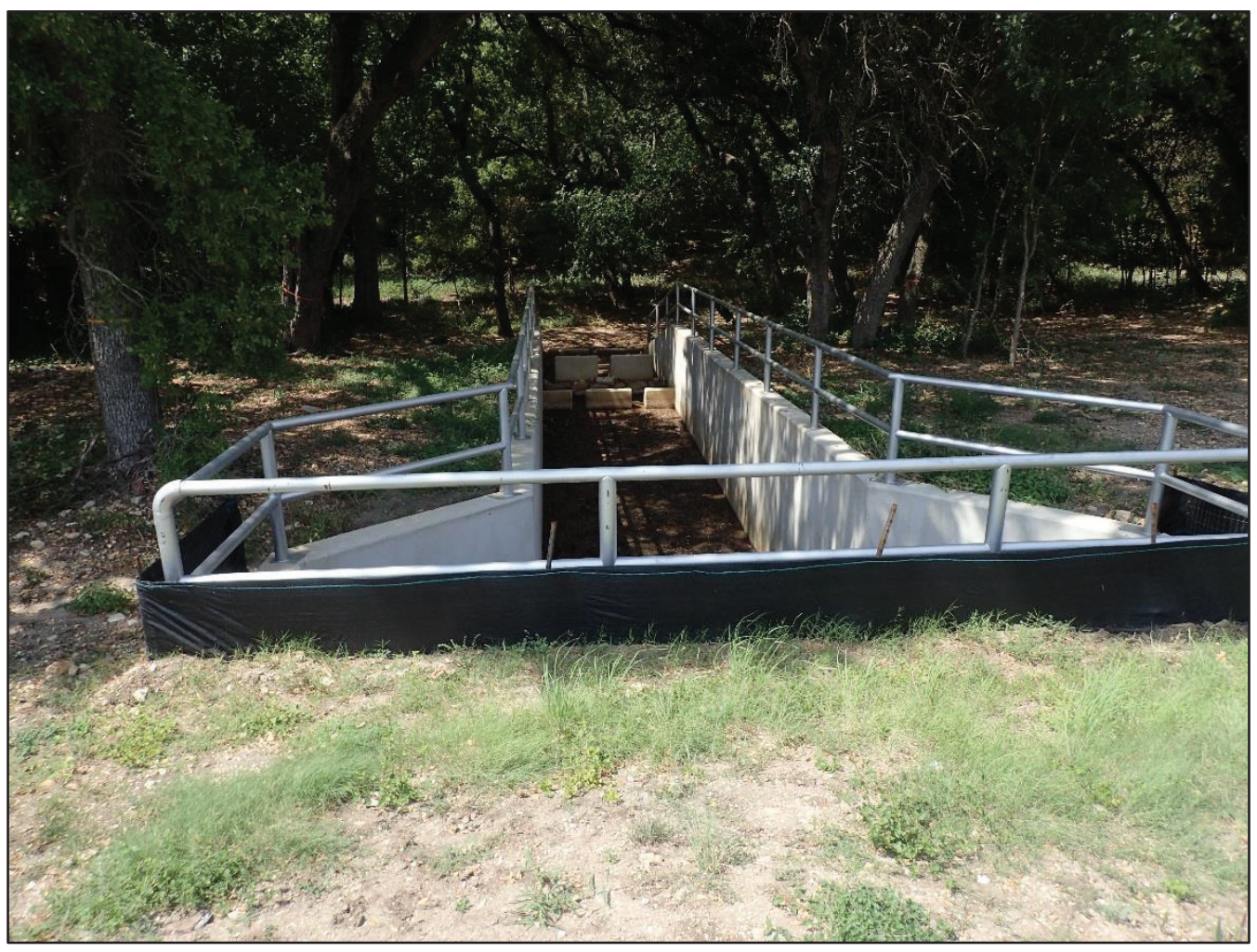

Figure 17. Large culvert running under Bulverde Road at the southern end of the APE, camera facing west. 


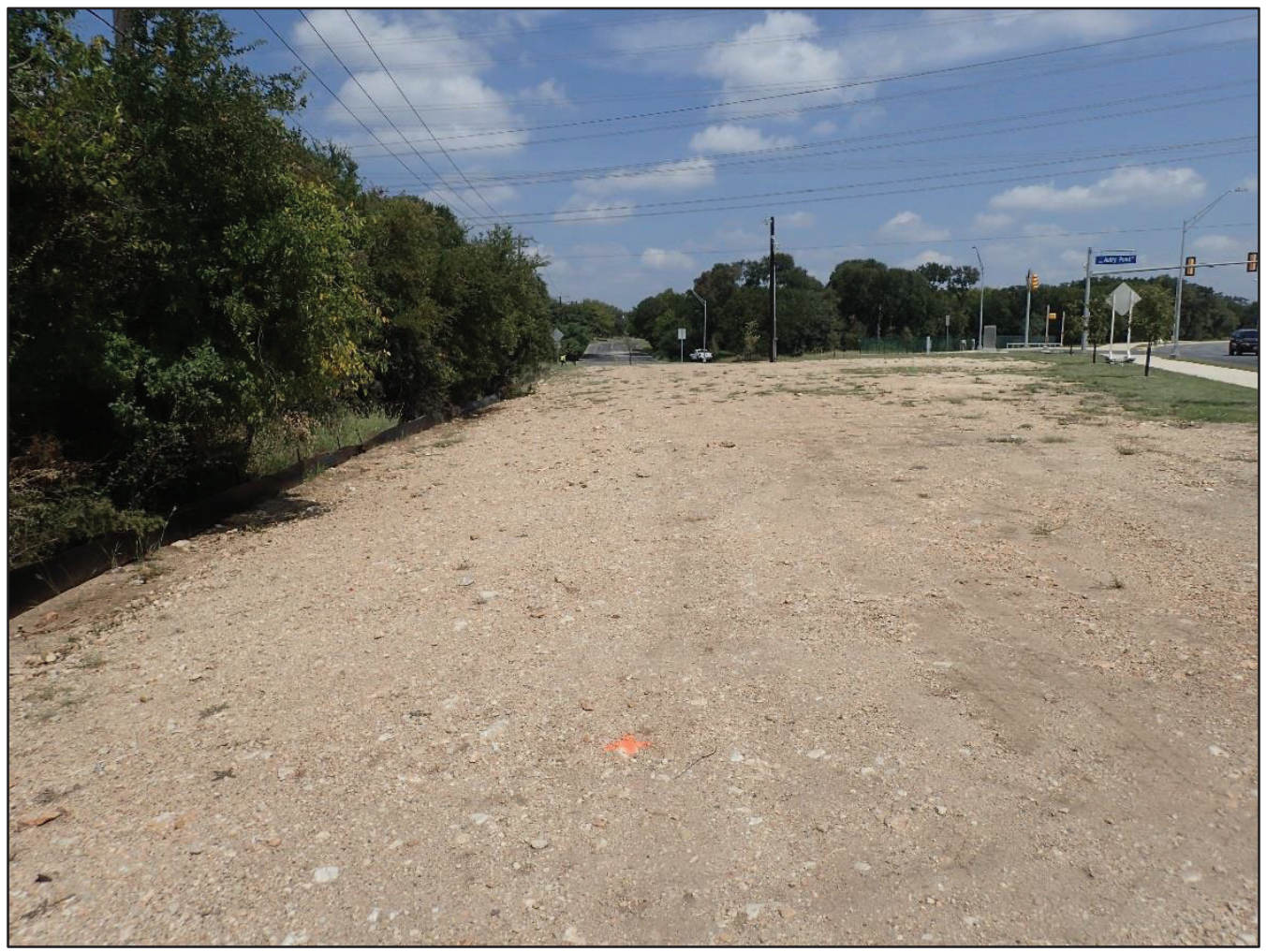

Figure 18. Disturbance along the western end of the APE, camera facing northeast (former location of Bulverde Road).

Archaeologists walked the entire APE visually inspecting the ground surface for artifacts and features. During the survey effort, a total of 16 shovel tests were excavated, all of which were negative for cultural material (Appendix A). Based on results of the background review, archaeologists focused the subsurface investigations in areas with the least known disturbance (see Figure 11). Most of the recorded intact soils were shallow gravely soils. These soils were generally dark gray to very dark grayish brown clay loam (ranging from 10YR4/1 to 10YR3/3) that contained a moderate to large number of cobbles and gravels. Half of the shovel tests $(n=8)$ encountered disturbed soils, and were typically terminated between 3 and $10 \mathrm{~cm}$ (1.2 and $4 \mathrm{in}$ ) below surface. No cultural resources were encountered during the excavation of the shovel test units.

The first portion of the APE investigated was between Classen Road and the newly constructed Bulverde Road and bridge. Archaeologist excavated four shovel tests within this area south of Elm Waterhole Creek and the existing sewer line. The deepest soils were encountered in this section of the APE with a maximum depth of $65 \mathrm{~cm}$ (25.6 in) below surface before terminating at bedrock (Figure 19). These soils appeared to be intact ancient alluvium. Two shovel tests that were excavated near the existing sewer line encountered mottled disturbed soils.

Between Bulverde Road and Autry Pond Road, archaeologists excavated eight shovel tests located along the north side of Elm Waterhole Creek and the existing line. Soils encountered in these shovel tests were shallow and gravelly unlike those mapped in the area (Figure 21). Of the eight shovel tests, two 
encountered mottled disturbed soils containing dense gravels and pebbles. One of these, VM04, was located near to a north running lateral of the existing sewer line. The other, MV03, was excavated between the sidewalk and the creek. The maximum shovel test depth reached in this portion of the APE was $30 \mathrm{~cm}$ (11.8 in) below surface before encountering impassable cobbles.

The next section of the APE is along Autry Pond Road where the APE crosses the road at a southwesterly angle then continues south along the west side of Bulverde Road to its intersection with Redland Road. Four shovel tests were placed along this stretch of the APE and all contained heavily disturbed soils, which were evidenced by the presence of modern debris including rubber hose fragments and bottle glass shards mixed with modern gravel fill (Figure 21). This disturbance is associated with the removal of a portion of Bulverde Road and subsequent construction of new road and sidewalks as well as an existing water line running through the APE.

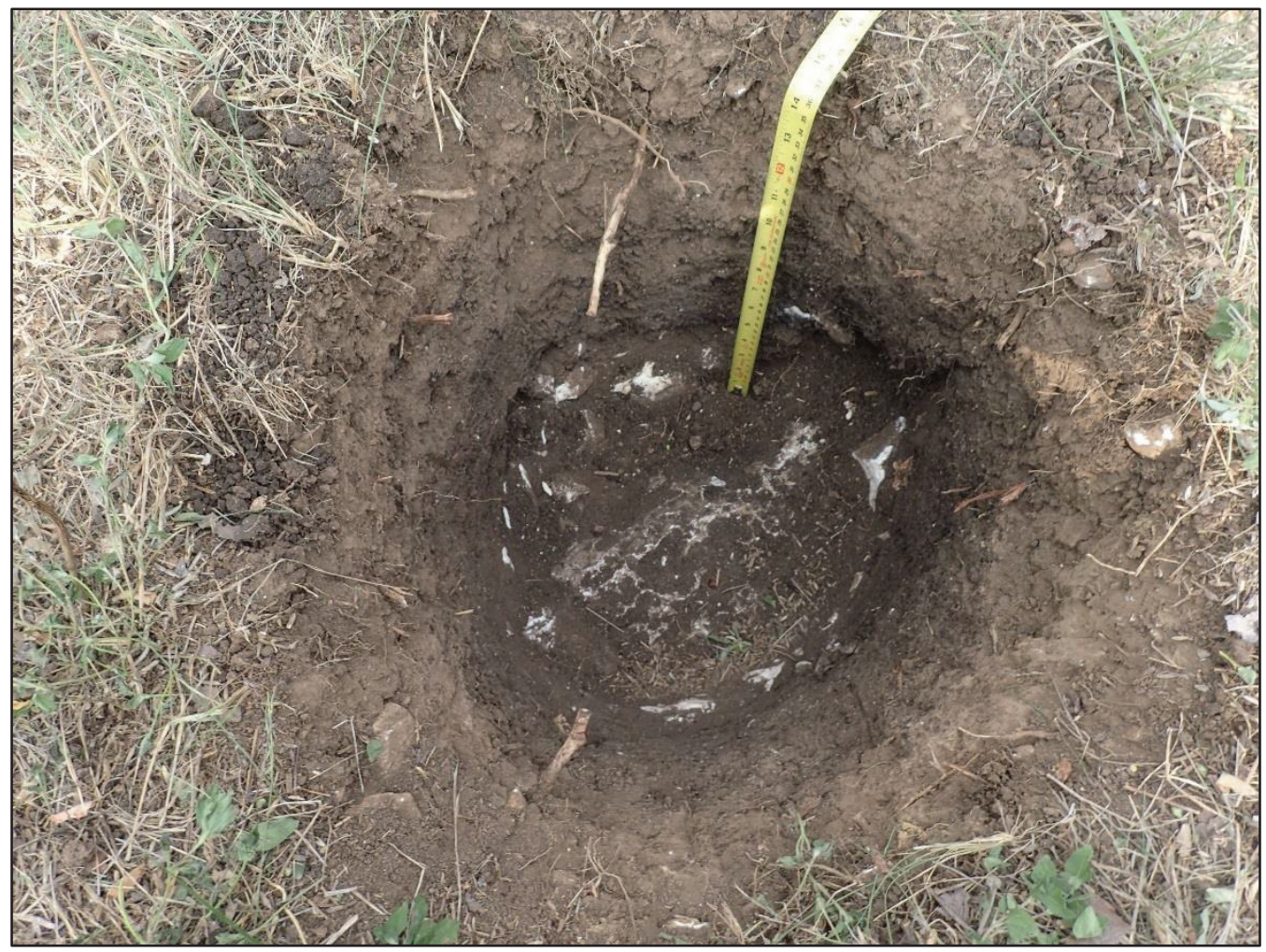

Figure 19. Example of shovel tests (VM01) with intact soils in the APE with large cobbles at $37 \mathrm{cmbs}$. 


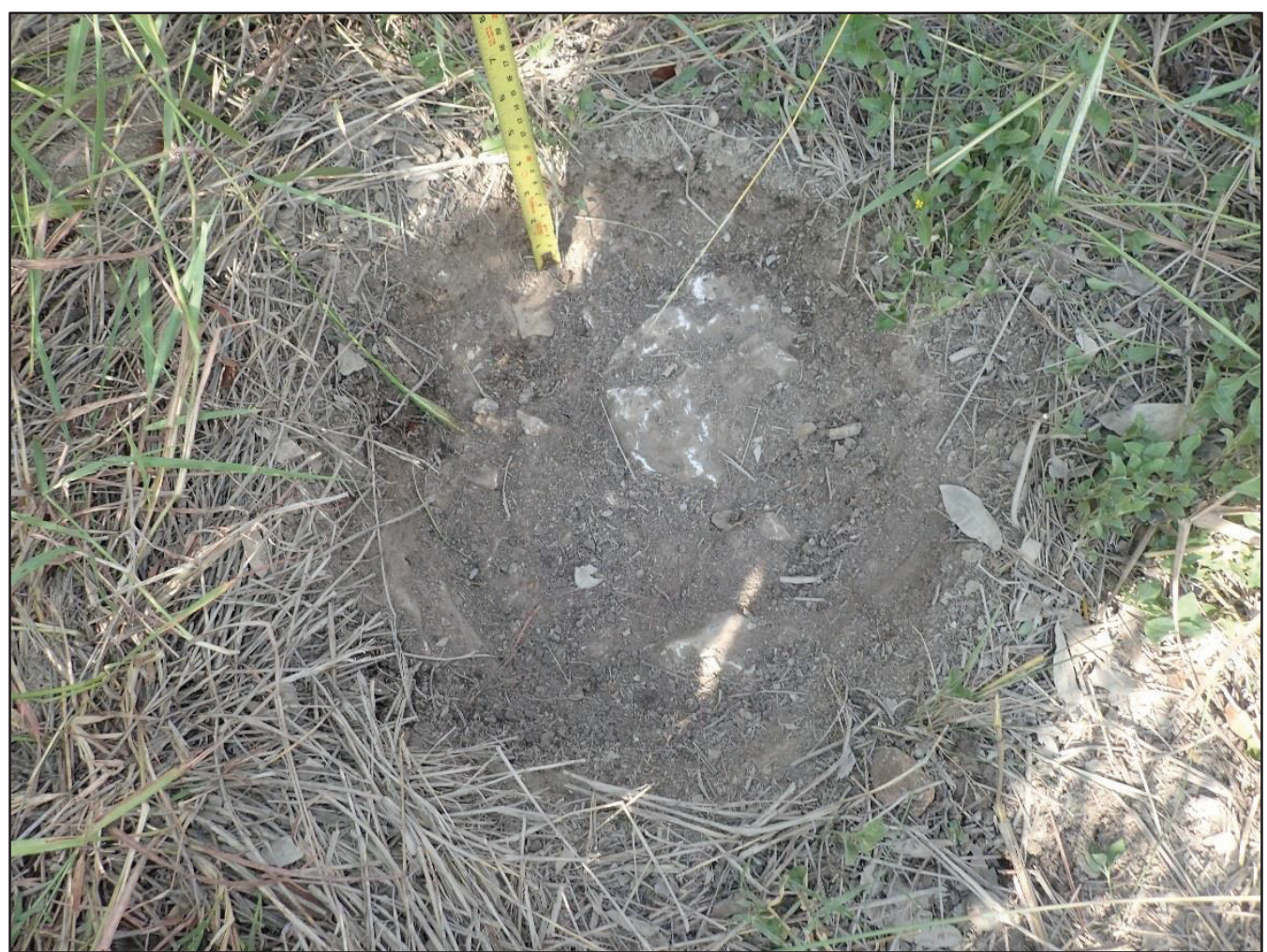

Figure 20. Example of shovel test (MV04) north of Elm Waterhole Creek with impassable cobbles.

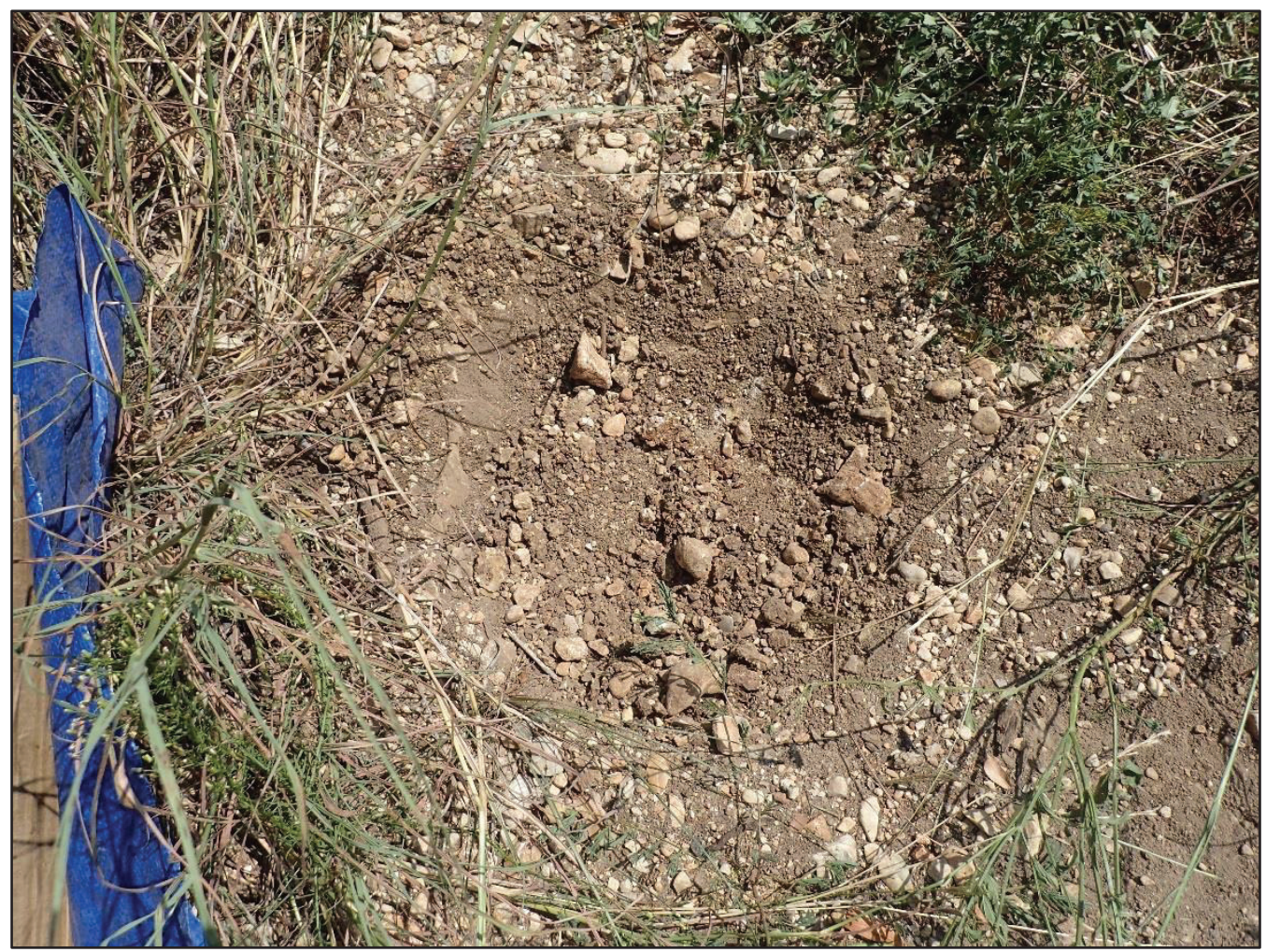

Figure 21. Example of shovel test (MV07) containing disturbed fill along western end of APE. 


\section{Site Description}

During the current survey, no new archaeological sites were encountered or recorded. However, a portion of previously recorded site 41BX1786 located within the project area was revisited. A detailed description of the revisited portion of the archaeological site is presented below.

\section{BX1786}

\section{Setting and Description}

Site 41BX1786 is a previously recorded superficial lithic scatter of indeterminate temporal affiliation located on a gently sloping upland terrace along the north side of Elm Waterhole Creek (Figure 22). The site was originally recorded by SWCA in 2008 during an archaeological survey of the Bulverde Marketplace Development project (Galindo 2008). Measuring $250 \mathrm{~m}$ (north to south) by $500 \mathrm{~m}$ (east to west), the site was reported to consist of lithic debitage, side and end scrapers, utilized flakes, cores, and burned rocks. However, the integrity of the site was largely destroyed during the construction of Bulverde Marketplace just north of the current APE (Figure 22). Vegetation at the site is currently characterized as medium to tall grasses in the existing SAWS ROW with live oak, persimmon, pecan, and mesquite trees on either side of the proposed SAWS line (Figure 23). Dense grasses and leaf litter limited ground surface visibility to less than 30 percent at the time of the survey (Figure 24 and Figure 25). 
This page has been redacted as

it contains restricted information 


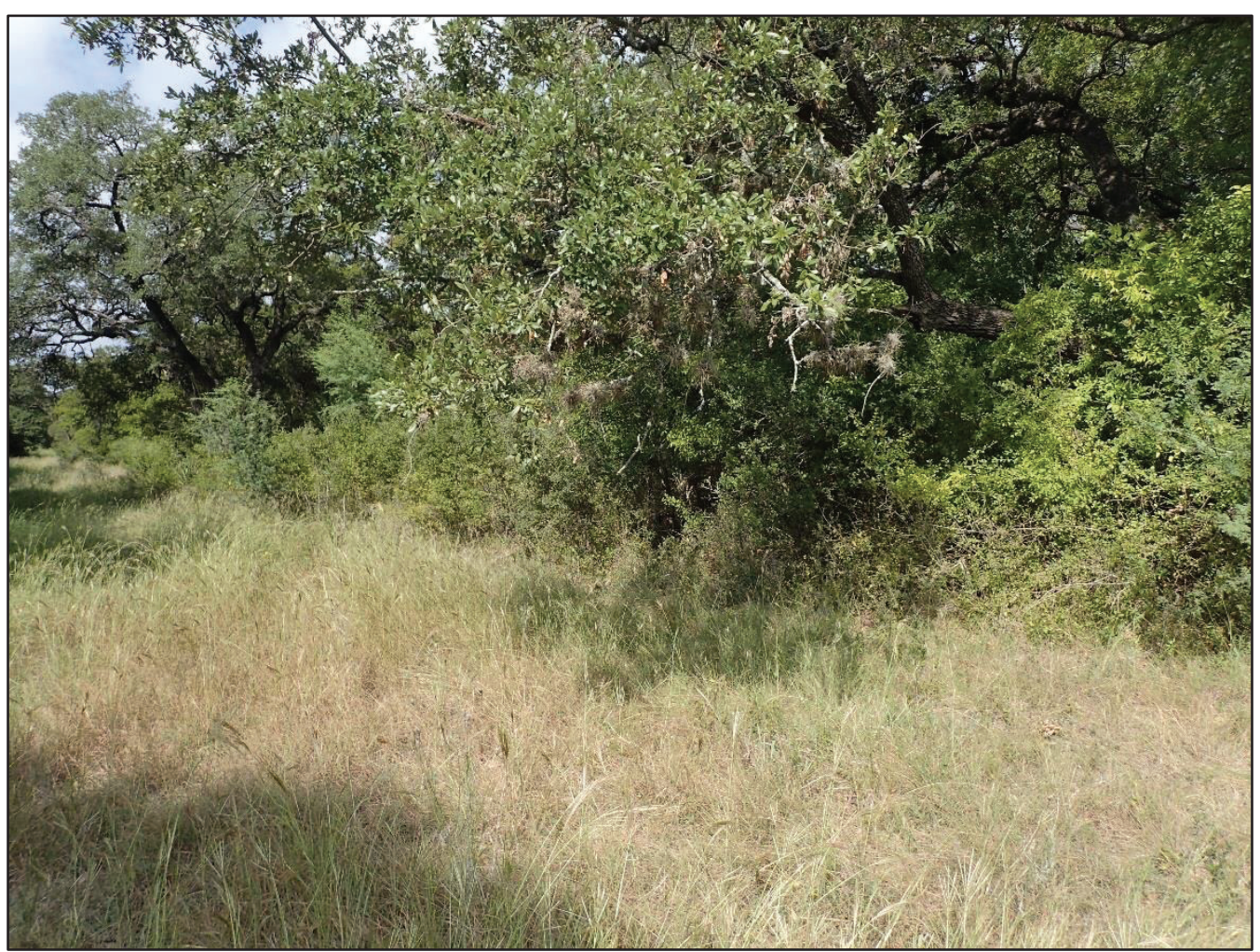

Figure 23. Overview of 41BX1786 from proposed centerline camera facing northwest.

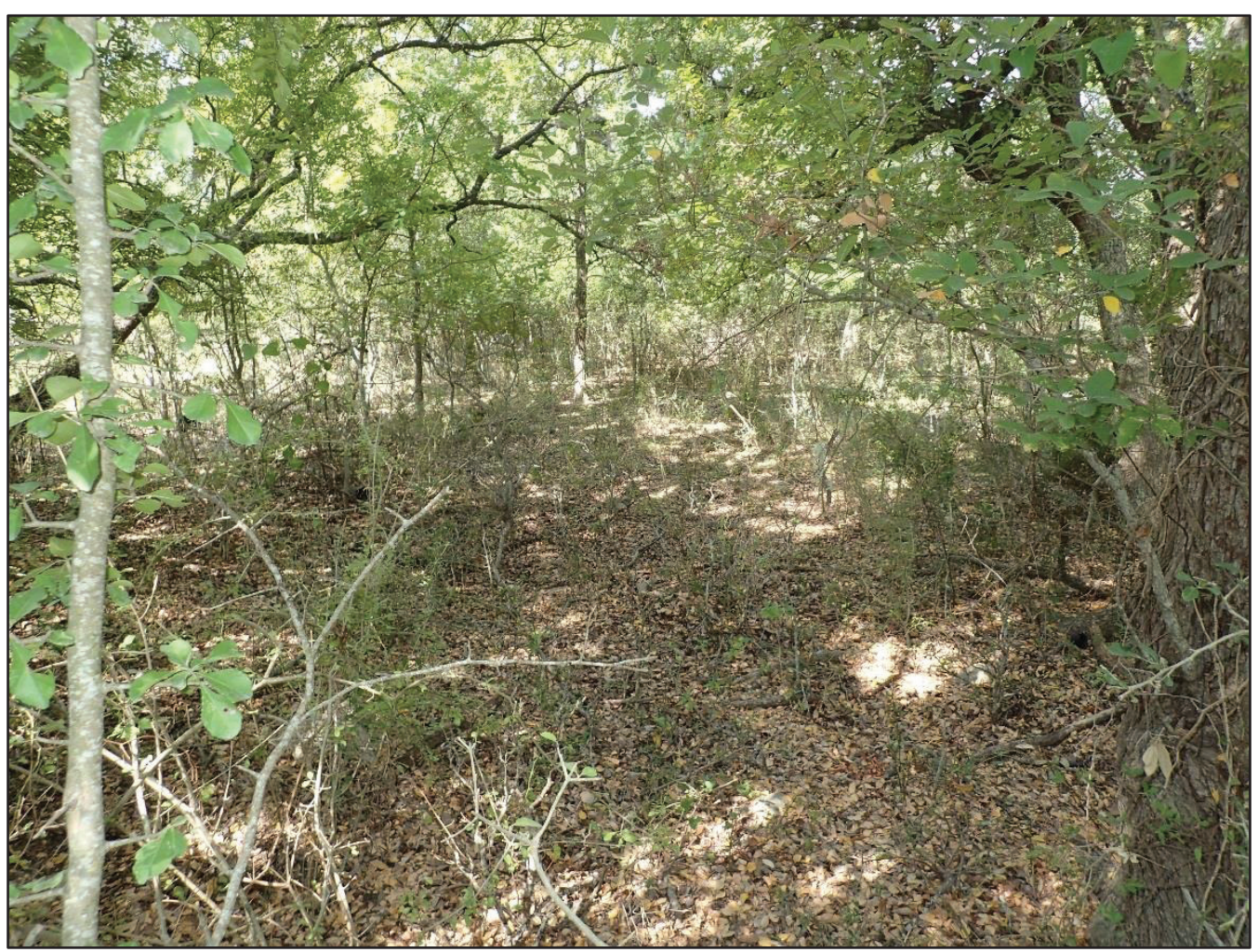

Figure 24. General view of 41BX1786 within the wooded sections of the APE, camera facing west. 


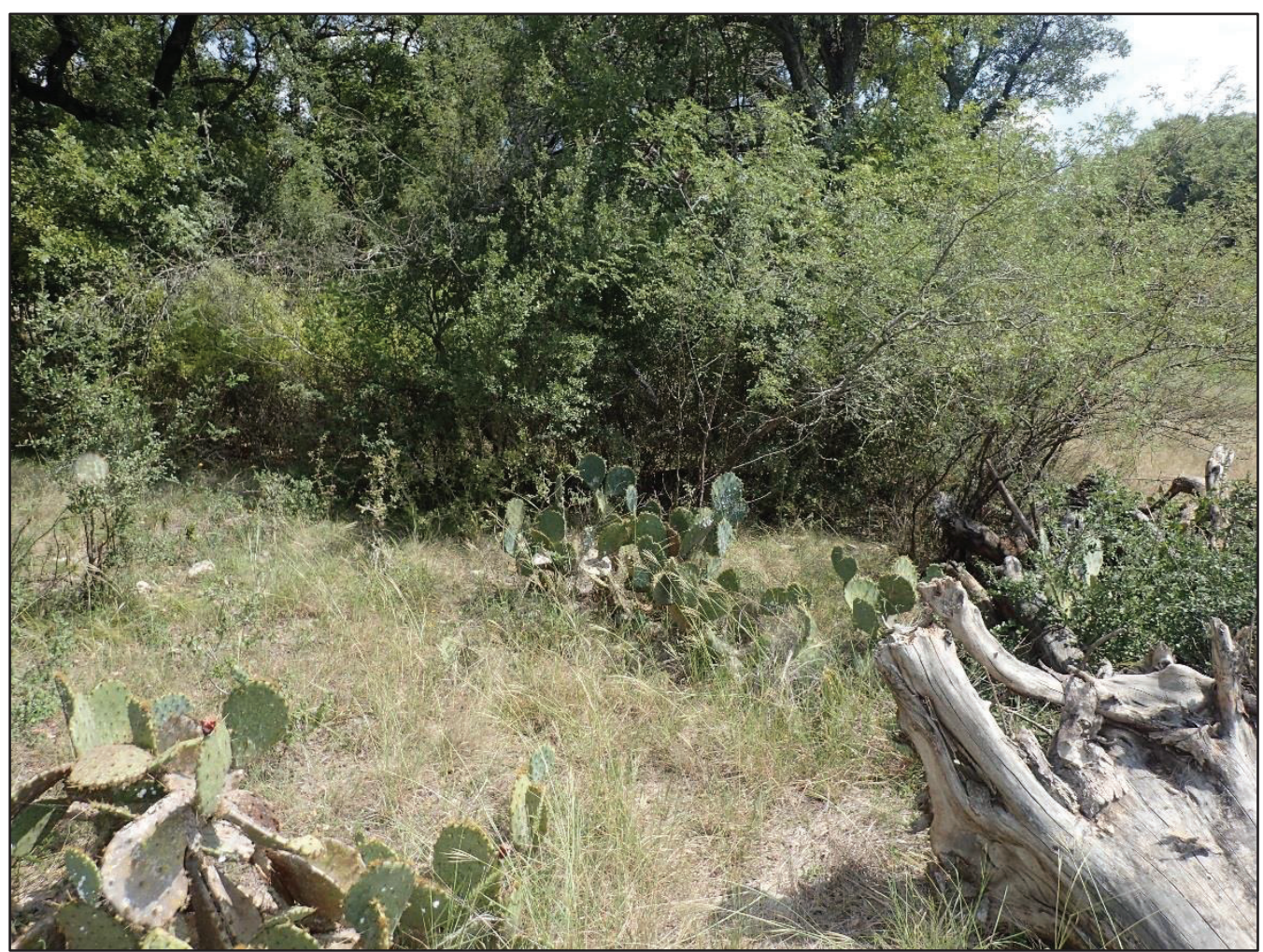

Figure 25. Example of less vegetated portions of 41BX1786, with dense short to medium grasses, camera facing east.

\section{Work Performed and Recommendation}

Pape-Dawson archaeologists revisited the portion of site 41BX1786 that is within the APE during the current survey. The ground surface was visually inspected, and six shovel tests were excavated to investigate the potential for subsurface archaeological deposits within and near the portion of the original site boundary that extends into the current APE (see Figure 5). Shovel tests exposed very dark brown to black clay loam with common limestone gravels, and were terminated between 2 and $30 \mathrm{~cm}(0.79$ to 12 in) below surface at impassable cobbles (Figure 26). The majority of soils mapped within the site boundary are Patrick silty clays with 1 to 3 percent slopes, with a small sliver mapped as Lewisville near the western end of the site (Taylor et al. 1991; USDA-NRCS 2017). Soils encounter within the shovel tests did not correspond to those mapped in the area. Generally, they were very shallow and gravely, more reminiscent of the Eckert cobbly clay mapped along the southern end of the APE. All shovel tests were negative for cultural material. No artifacts were observed on the ground surface. However, ground surface visibility at the site was limited by dense grasses and leaf litter. 


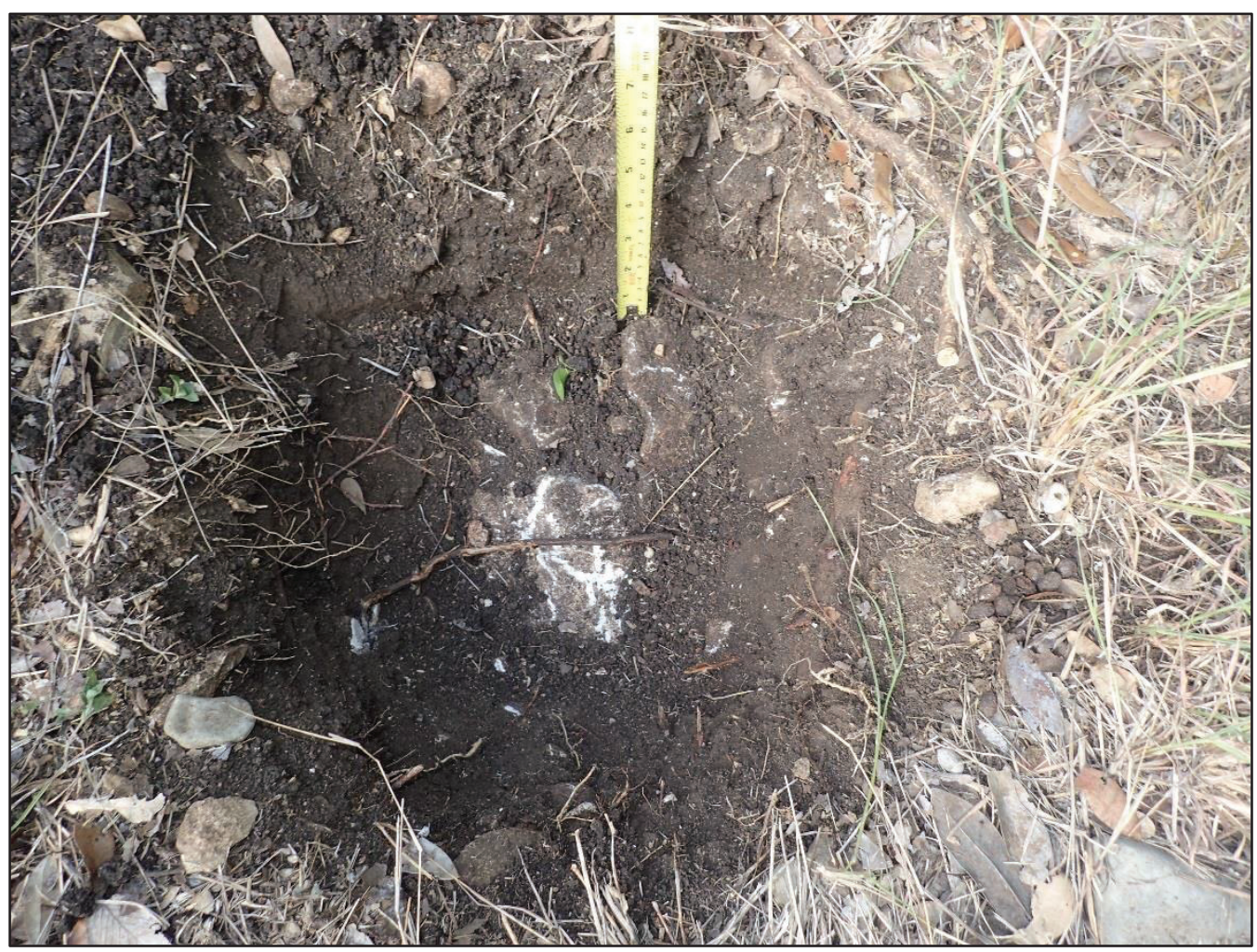

Figure 26. Typical shovel test profile encountered in site 41BX1786.

\section{Summary and Recommendations}

Pape-Dawson conducted an intensive archaeological survey of the proposed NWC Bulverde/1604 Sewer Extension Project in San Antonio, Bexar County, Texas, on behalf of SAWS. The proposed sewer line would parallel Elm Waterhole Creek to the west and south approximately $0.8 \mathrm{~km}$ ( 0.5 mile) before crossing Autry Pond Road in a southwestern direction and eventually paralleling Bulverde Road to the intersection of Redland Road for a total length of approximately $0.4 \mathrm{~km}(0.25$ mile). This project would entail the installation of $1.2 \mathrm{~km}$ ( 0.75 mile) of new sewer line within a $5-\mathrm{m}(16-\mathrm{ft})$-wide permanent easement. The APE for the proposed project was defined as a $30-\mathrm{m}$ (100-ft) buffer centered on the proposed SAWS centerline with total area of 3.7 ha (9.18 acres). The depth of vertical impacts was not determined, but utility installations typically require 1.8 to $2.4 \mathrm{~m} \mathrm{(6} \mathrm{to} 8 \mathrm{ft}$ ). Notably, the sewer alignment was changed after completion of this archaeological survey and installation will no longer take place in this APE. The survey for the new alignment was completed under Texas Antiquities Permit \#8870.

Although Oden Hughes would construct the new sewer line, SAWS would be the grantee of the easement after construction. For this reason, compliance with the ACT was required. In addition, this project would require a Nationwide Permit from the USACE. Thus, compliance with Section 106 of the NHPA (36 CFR 800.4) would be required. In addition, the project was located within the San Antonio city limits, which necessitated compliance with the Historic Preservation and Urban Design Section of the COSA UDC. 
Pape-Dawson conducted an archaeological investigation on September 20, 2017, for the proposed NWC Bulverde/1604 Sewer Extension project, with Virginia Moore serving as Principal Investigator under Antiquities Permit No. 8161. The entirety of the APE was subjected to an intensive archaeological survey. Results of the survey found much of the APE to be heavily disturbed. A total of 16 shovel tests were excavated to investigate the APE in areas displaying minimal disturbance. All shovel tests were negative for archaeological material. During this survey, one previously recorded site (41BX1786) was revisited within the limits of the APE. However, no cultural material associated with site 41BX1786 were encountered. Given the absence of artifacts observed during the current survey, PapeDawson recommends that $41 \mathrm{BX} 1786$ is ineligible within ROW for State Antiquities Landmark (SAL) and National Register of Historic Places (NRHP) designation.

In accordance with 36 CFR 800.4, Pape-Dawson made a reasonable and good faith effort to identify archaeological historic properties within the APE. As no properties were identified that meet the criteria for listing in the NRHP according to 36 CFR 60.4, or for designation as a SAL according to 13 TAC 26.12, Pape-Dawson recommends that no further archaeological work is necessary for the proposed undertaking as presently designed and that the project be allowed to proceed within the APE. However, if cultural material is encountered during construction, it is recommended that all work in the vicinity should cease and that the discovery be evaluated by a qualified archaeologist who can provide guidance on how to proceed in accordance with federal, state, and local regulations. 


\section{References Cited}

Acuña, Laura

2016 CPS Energy 2014 Annual Permit: Final Report for Eight CPS Energy Projects under Antiquities Permit Number 6851, Bexar County, Texas. SWCA Cultural Resources Report No. 15-669. SWCA Environmental Consultants, San Antonio.

Black, S.L.

1989 South Texas Plains. In From the Gulf to the Rio Grande: Human Adaptation in Central, South, and Lower Pecos Texas, edited by T.R. Hester, S.L. Black, D.G. Steele, B.W. Olive, A.A. Fox, K.J. Reinhard, and L.C. Bement, pp. 38-62. Center for Archeological Research, The University of Texas at San Antonio and the Arkansas Archeological Survey, Fayetteville.

Black, Steve and Al J. McGraw

1985 Panther Springs Creek Site: Cultural Change and Continuity Within the Upper Salado Creek Watershed, South-Central Texas. Archaeological Survey Report, No. 100. Center for Archeological Research, The University of Texas at San Antonio.

Bousman, C.B., B.W. Baker, and A.C. Kerr

2004 Paleoindian Archeology in Texas. In The Prehistory of Texas, edited by T.K. Perttula, pp 15-99.

Campbell, T.N.

1977 Ethnic Identities of Extinct Coahuiltecan Populations: Case of the Juanca Indians. The Pearce-Sellards Series 26. Texas Memorial Museum, Austin.

Collins, Michael B.

1995 Forty Years of Archeology in Central Texas. In Bulletin of the Texas Archeological Society 66:361400.

2004 Archeology in Central Texas. In The Prehistory of Texas. Edited by Timothy K. Perttula, pp. 101126. Texas A\&M University Press, College Station.

Collins, Michael B., Dale B. Hudler, and Stephen L. Black

2003 Pavo Real: A Paleoindian and Archaic Camp and Workshop on the Balcones Escarpment, SouthCentral Texas. Antiquities Permit No. 249. TxDOT Archeological Studies Program, Texas Archeological Research Laboratory, The University of Texas, Austin.

de la Teja, J.F.

1995 San Antonio De Bexar: A Community on New Spain's Northern Frontier. University of New Mexico Press.

Dockall, J.E., D.K. Boyd, and L.E. Kittrell

2006 Geoarcheological and Historical Investigations in the Comal Springs Area, LCRA Clear Springs Autotransformer Project, Comal County, Texas. Investigation No. 149. Antiquities Permit No. 3850. Prewitt \& Associates, Inc., Austin. 
Fehrenbach, T.R.

2017 San Antonio, TX. Handbook of Texas Online, accessed October 4, 2017. https://www.tshaonline.org/handbook/online/articles/hds02. Uploaded on June 15, 2010. Modified on March 30, 2017. Published by the Texas State Historical Association.

Figueroa, Antonia L., and Charles D. Frederick

2008 Archeological Testing of the Pavo Real Site (41BX52), San Antonio, Bexar County, Texas. Archaeological Report No. 382. Antiquities Permit No. 4092. Center for Archaeological Research, The University of Texas, San Antonio.

Fisher, Lewis F.

2014 San Antonio River Walk [Paseo Del Rio], Handbook of Texas Online, accessed October 4, 2017, http://www.tshaonline.org/handbook/online/articles/hps02. Uploaded on June 15, 2010. Modified on January 29, 2014. Published by the Texas State Historical Association.

Galindo, Mary Jo

2008 Intensive Cultural Resources Survey of the Bulverde Marketplace Development Bexar County, Texas. SWCA Cultural Resources Report Number 2008-384. SWCA Environmental Consultants. Austin, Texas.

Google Earth

2017 Various aerial images, accessed September 18, 2017.

Hester, T.R.

1978 Early Human Occupation in South Central and Southwestern Texas: Preliminary Papers on the Baker Cave and St. Mary's Hall sites. Center for Archaeological Research, The University of Texas at San Antonio.

Long, Christopher

2017 Bexar County. Handbook of Texas Online, accessed October 4, 2017. http://www.tshaonline.org/handbook/online/articles/hcb07. Uploaded on June 12, 2010. Modified on March 30, 2017. Published by the Texas State Historical Association.

McNatt, L., C. Beceiro, M.D. Freeman, S.A. Tomka, P. Schuchert, and C.G. Ward

2000 Archeological Survey and History of Government Canyon State Natural Area, Bexar County, Texas. Antiquities Permit No. 1669. Cultural Resources Program, Texas Parks and Wildlife, Austin.

Mercado-Allinger, P.A., N.A. Kenmotsu, and T.K. Perttulla

1996 Archeology in the Central and Southern Planning Region, Texas: A Planning Document. Office of the State Archeologist, Special Report 35 and the Department of Antiquities Protection Cultural Resource Management Report 7. Texas Historical Commission, Austin.

Nationwide Environmental Title Research (NETR Online)

2017 Aerial Imagery of San Antonio, Texas. http://www.historicaerials.com/ (accessed September 1, 2017). 
Pertulla, T.K. (editor)

2004 The Prehistory of Texas. Texas A\&M University Press, College Station.

Prewitt, E.R.

1981 Cultural Chronology in Central Texas. Bulletin of the Texas Archeological Society 52:65-89.

1982 Archeological Investigations at the Loeve-Fox Site, Williamson County, Texas. Reprints in Archeology Number 1. Prewitt \& Associates, Austin.

Spell, Lota M. (translation)

1962 The Grant and First Survey of the City of San Antonio. The Southwestern Historical Quarterly, Vol. LXVI, No. 1.

Taylor, F. B., R. Hailey, and D. L. Richmond

1991 Soil Survey of Bexar County, Texas. U. S. Department of Agriculture, Soil Conservation Service, in cooperation with the Texas Agricultural Experiment Station, Washington, D.C.

Tennis, C.L.

1996 Archaic land use of upper Leon Creek terraces: Archeological testing in northern Bexar County, Texas. Archeological Survey Report No. 234. Center for Archaeological Research, The University of Texas at San Antonio.

Texas Historical Commission (THC)

2017 Archeological Sites Atlas. Restricted-access database. http://nueces.thc.state.tx.us/ (Accessed October 4, 2017).

Thoms, A.V., and R. D. Mandel (editors)

2007 Archaeological and Paleoecological Investigations at the Richard Beene Site, South-Central Texas. Technical Report Series No. 8. 2 Vols. Center for Ecological Archaeology, Texas A\&M University, College Station.

Thoms, A.V., P.A. Claybaugh, S. Thomas, and M. Kamiya

2005 Archaeological Survey and Monitoring in 2005 at the Richard Beene Site, South-Central Texas. Technical Report Series No. 7. Antiquities Permit No. 3836. Texas A\&M

Turner, E. S. and T. R. Hester

1993 A Field Guide to Stone Artifacts of Texas Indians. Gulf Publishing Co., Houston.

United States Geological Survey (USGS)

2005 Texas Geologic Map Data. USGS Mineral Resources On-Line Spatial Data. Web. (accessed October 4, 2017).

Wermund, E.G.

1996 Physiographic Map of Texas. Bureau of Economic Geology. The University of Texas at Austin.

Wright, Robert E., O.M.I. 
2016 Handbook of Texas Online, "Spanish Missions," accessed October 4, 2017, http://www.tshaonline.org/handbook/online/articles/its02. Uploaded on June 15, 2010. Modified on June 13, 2016. Published by the Texas State Historical Association. 
Appendix A

Shovel Test Data 
Table A-1. Shovel Test Data

\begin{tabular}{|c|c|c|c|c|c|c|c|c|c|}
\hline ST \# & Site & Level & Depth & $\begin{array}{l}\text { Positive/ } \\
\text { Negative }\end{array}$ & Munsell & Soil Color & Soil Texture & $\begin{array}{l}\text { Cultural } \\
\text { Material }\end{array}$ & Comments/Reason for Termination \\
\hline MV02 & & $0-1$ & $0-3$ & N & 10YR5/2 & Grayish Brown & $\begin{array}{l}\text { Cobbly Clay } \\
\text { Loam }\end{array}$ & None & $\begin{array}{c}\text { ASV }=0 \% \text {. Tall grasses and oaks. South } \\
\text { of the creek. Many cobbles. } \\
\text { Impenetrable cobbles. Distrubed. }\end{array}$ \\
\hline MV03 & & $0-1$ & $0-3$ & $\mathrm{~N}$ & 10YR6/1 & Gray & Cobbly Silt & None & $\begin{array}{l}\text { ASV }=50 \% \text {; Northwest of Bulverde road } \\
\text { All soil distubed by ditch. Impenetrable } \\
\text { cobbles. Distrurbed. }\end{array}$ \\
\hline MV05 & 41BX1786 & $0-1$ & $0-3$ & $\mathrm{~N}$ & 10YR2/1 & Black & Clay Loam & None & $\begin{array}{l}\text { ASV }=20 \% . \text { Leaf litter; many oaks. Many } \\
\text { roots and cobbles. Terminated at } \\
\text { impenetrable limestone cobbles. }\end{array}$ \\
\hline MV06 & 41BX1786 & $0-3$ & $0-30$ & $\mathrm{~N}$ & 10YR2/1 & Black & Clay Loam & None & $\begin{array}{c}\text { ASV }=20 \% . \text { Leaf litter, hackberry and } \\
\text { many oask. Terminated at } \\
\text { impenetrable limestone cobbles. }\end{array}$ \\
\hline MV07 & & $0-1$ & $0-3$ & N & 10YR5/2 & Grayish Brown & Silt & None & $\begin{array}{l}\text { Many cobbles. Gravels and fill on the } \\
\text { surface from construction. Disturbed. }\end{array}$ \\
\hline MV08 & & $0-1$ & $0-3$ & $\mathrm{~N}$ & 10YR2/1 & Black & $\begin{array}{l}\text { Silt with } \\
\text { gravels }\end{array}$ & None & $\begin{array}{l}\text { Right next to Autry Pond road. Many } \\
\text { gravels. Built up, disturbed soil. } \\
\text { Gravels and fill on the surface from } \\
\text { construction. Disturbed. }\end{array}$ \\
\hline
\end{tabular}


Table A-1. Shovel Test Data

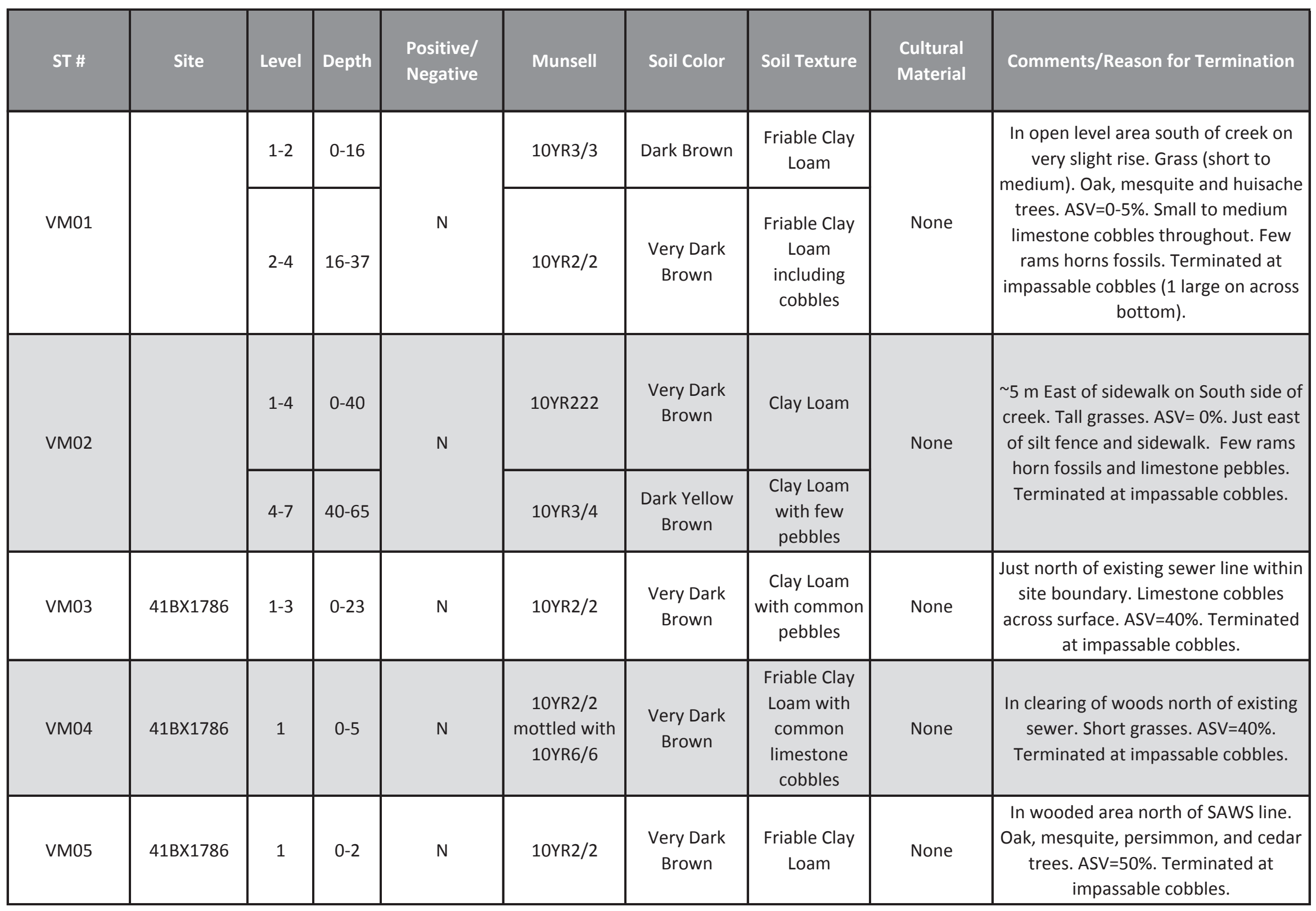


Table A-1. Shovel Test Data

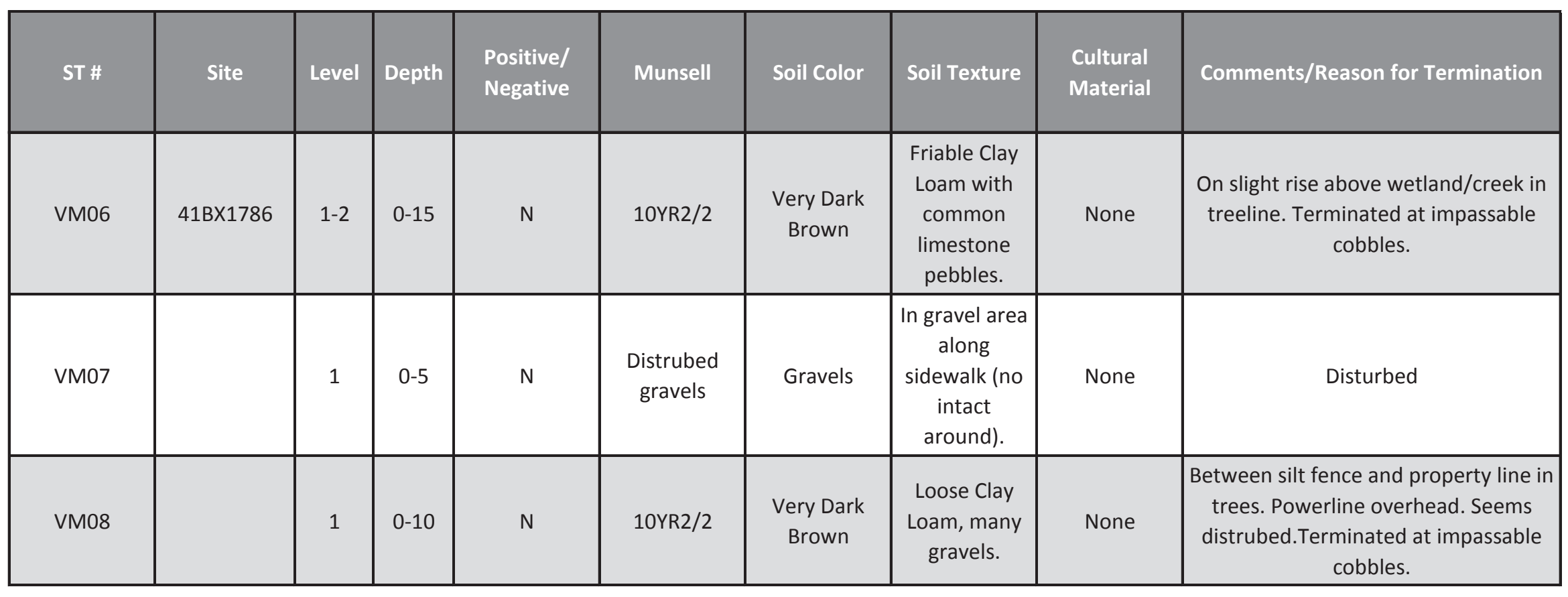

